Hydroécol. Appl. (1989) 1/2, pp. 85-116

\title{
Monitoring the quality of water in the Doubs river (France)
}

\author{
Ph. Gosse
}

Electricité de France Département Environnement aquatique et atmosphérique 6, quai Watier 78400 Chatou - France

\begin{abstract}
The water quality measurements carried out in 1981 at six stations on the lower Doubs were exploited for the development of a dissolved oxygen model. A length of the river of $170 \mathrm{~km}$ was considered, comprising the towns of Baume-les-Dames, Besançon and Dole. With a time step of three hours, the model reconstitutes the evolution of 8 water quality parameters and phytoplankton biomass for the years 1981 and 1982. By means of this model, we evaluate on a semesterial scale (May-October) the magnitude of the different terms of the dissolved oxygen balance; which shows the major role played by phytoplankton biomass. A predictive application of the model is given: it indicates possible trends in the dissolved oxygen profiles for the Doubs supposing the realization of the Rhine-Rhone large tonnage project.
\end{abstract}

Résumé - On exploite les mesures de qualité d'eau collectées en 1981 en 6 stations du Doubs inférieur, pour mettre au point un modèle numérique d'oxygène dissous de la rivière sur un tronçon de 170 kilomètres, comprenant les villes de Baume-les-Dames, Besançon et Dole. Le modèle permet de reconstituer avec un pas de temps trihoraire l'évolution de 8 paramètres de qualité d'eau et de la biomasse phytoplanctonique le long du tronçon, pendant les années 1981 et 1982. A l'aide du modèle, on évalue à l'échelle semestrielle (mai-octobre) l'ordre de grandeur des différents termes du bilan d'oxygène dissous, ce qui montre le rôle important joué par la biomasse végétale planctonique. On donne une application prédictive du modèle montrant les profils d'oxygène dissous que l'on aurait pû observer pour les conditions des années 1981 et 1982, en supposant réalisé le projet de mise à grand gabarit du canal Rhin-Rhône.

\section{Présentation de l'article}

After a presentation in French, the article written in English begins on page 88.
Comment évolue l'oxygène dissous au cours de l'année sur le Doubs inférieur entre Montbéliard et Dole ? Quels changements observerait-on 
pour ce paramètre si l'on réduisait certains apports organiques et minéraux d'origine industrielle, agricole ou domestique ou si l'on réalisait le projet de mise à grand gabarit du canal Rhin-Rhône ?

Pour permettre de répondre à ces questions, nous avons développé entre les années 1981 et 1983 un modèle numérique déterministe d'oxygène dissous à la demande de la Direction Régionale de l'Equipement de Franche-Comté. S'appuyant sur une structure unidimensionnelle, qui considère une valeur moyenne en chaque section transversale de la rivière, ce modèle a été conçu pour examiner les évolutions de façon globale sur près de 200 kilomètres de rivière avec comme premier objectif la mise en évidence des tronçons potentiellement les plus critiques sur le plan oxygénation. Des études à échelle spatiale plus fine pourront éventuellement compléter cette approche, en particulier pour étudier les écosystèmes particuliers des berges.

Pour disposer d'un modèle très fiable, l'idéal aurait été de concevoir un réseau de mesures in situ spécialement adapté pour sa mise au point et sa vérification. Malheureusement, une telle démarche est rarement possible en écologie aquatique, tout simplement parce que les budgets disponibles pour les campagnes de mesures ne sont généralement pas à l'échelle des besoins nécessaires à une bonne compréhension du fonctionnement des écosystèmes.

La démarche la plus classique qui a été retenue ici - consiste à utiliser les résultats d'un réseau de me- sures existant - dans notre cas, il s'agissait du réseau de mesures du SRAE Franche-Comté mis en place en 1974 au moment de l'opération sauvetage du Doubs - et à renforcer temporairement ce réseau pour acquérir, dans la limite du budget disponible, quelques données essentielles pour la mise au point du modèle ici ce sont les mesures réalisées par le CEMAGREF et le SRAE en 1981 et 1982.

Dans ces conditions quelque peu restrictives, il arrive souvent - comme c'est le cas ici - que les facteurs importants suivants du bilan d'oxygène dissous ne soient pas mesurés bien qu'ils jouent un grand rôle : la réaération (échanges physiques d'oxygène à l'interface eau-atmosphère), la demande benthique en oxygène (consommation chimique et biologique d'oxygène à l'interface sol-eau) et la variabilité temporelle des rejets oxydables.

On doit de ce fait accepter une certaine perte de fiabilité du modèle numérique, dont une première utilisation va consister à s'assurer de la vraisemblance des hypothèses faites sur ces données manquantes, au moment de la phase d'ajustement du calcul sur les mesures de qualité d'eau disponibles en différentes stations : ces dernières, qui constituent les points de contrôle du modèle, sont au nombre de cinq dans notre étude (figure 1) : Baumes-les-Dames, Deluz, Avanne, Orchamps et Gévry, situées respectivement $48,67,95,141$ et 169 kilomètres en aval de Lougres, limite amont du modèle. 
Pour décrire le mieux possible l'oxygène dissous, dans la situation actuelle ou pour des études prédictives, 8 autres variables ont également été simulées par le modèle: la température de l'eau, la charge oxydable détritique ou DBO, l'azote organique détritique, l'azote ammoniacal, l'azote nitrique, le phosphore organique détritique, les orthophosphates et la biomasse phytoplanctonique. Le principe du modèle est de calculer toutes les trois heures sur plusieurs cycles annuels la valeur de ces 9 variables sur l'ensemble du tronçon Lougres-Gévry, avec un pas d'espace de l'ordre de 10 kilomètres.

Après une analyse des mesures collectées, l'article présente les phases d'étalonnage et de vérification du modèle. On précise l'ordre de grandeur des différents termes du bilan d'oxygène dissous calculé, puis on donne une application prédictive du modèle en examinant l'impact possible du projet de mise à grand gabarit du canal Rhin-Rhône sur l'oxygène dissous du Doubs.

L'article présenté a été rédigé en 1984 sur la base des 6 rapports d'étude (en français) remis par EDF à la Direction Régionale de l'Equipement entre les années 1981 et 1984, documents que l'on peut obtenir, sur demande auprès de cet organisme (adresse en fin d'article). Ce modèle de qualité d'eau du Doubs n'a pas fait l'objet de perfectionnement depuis cette date : il a été appliqué en 1987 et 1988 - à la demande de l'Agence de l'Eau Rhône - Méditerranée Corse - pour évaluer l'ordre de gran- deur des diminutions d'apports de phosphore et d'azote qui permettraient de limiter sensiblement le développement phytoplanctonique dans le Doubs inférieur (voir références de ce bas de page). Cette orientation des études actuelles vers l'examen des problèmes d'eutrophisation nous amène à l'idée qu'un perfectionnement intéressant du modèle consisterait à augmenter le nombre des variables simulées en ajoutant la biomasse végétale fixée. En effet, une baisse sensible des concentrations de phytoplancton, due à une réduction des apports de phosphore ou d'azote, devrait permettre une certaine réduction de la turbidité de l'eau en été. Les conditions d'éclairement deviendraient alors plus favorables pour le développement des végétaux fixés. Comme par ailleurs, pour assurer leur croissance, ces végétaux sont beaucoup moins exigeants que le phytoplancton sur les concentrations d'azote et de phosphore dans l'eau, ils pourraient devenir dans ce cas un facteur très important du bilan d'oxygène dissous du Doubs inférieur.

Références récentes d'applications du modèle développé sur le Doubs

GOSSE, Ph., GRAS, R., SALLERON, J.L., LEGLIZE, L., 1986 : Approches successives dans le contrôle de l'eutrophisation d'une rivière : le Doubs, la Moselle et la Meuse. In. L'impact des activités humaines sur les eaux continentales.

Question $n^{\circ} 111$, rapport $n^{0} 4$ - Société Hydrotechnique de France (19e journées de l'hydraulique) 
GOSSE, Ph., LASCOMBE, C., SALLERON, J.L., 1989 : Modélisation de la qualité de grands cours d'eau : eutrophisation, cas de la Moselle et du Doubs. Article à paraître dans comptes-rendus de la session Société Hydrotechnique de France, novembre 1989, sur le thème modèles mathématiques pour la gestion de la qualité des eaux.

\section{INTRODUCTION}

The source of the Doubs lies in the Jura mountain, whence the river flows to the north-east towards Switzerland, and then bifurcates in the vicinity of Monbéliard, turning to the south-west. It then flows through the towns of $\mathrm{Be}$ - sançon (population : 130 000) and Dole (pop. : 40000 ) where it joins the river Saône, a tributary of the Rhône (figure 1). A small canal built in the last century links with the Doubs at many points and allows for small tonnage navigation between the Saône and the Rhine. Like many other streams, eg, the Ognon and the Loue, the Doubs river, which is much appreciated by anglers has made the Franche Comté a popular region for fishing.

However, the industrial boom of the 1960 's in the Doubs valley, especially in the Montbéliard region, deteriorated water quality substantially and jeopardized the hospitable character of water for fish.

As a result, in 1974, the Ministry of the Environment launched the

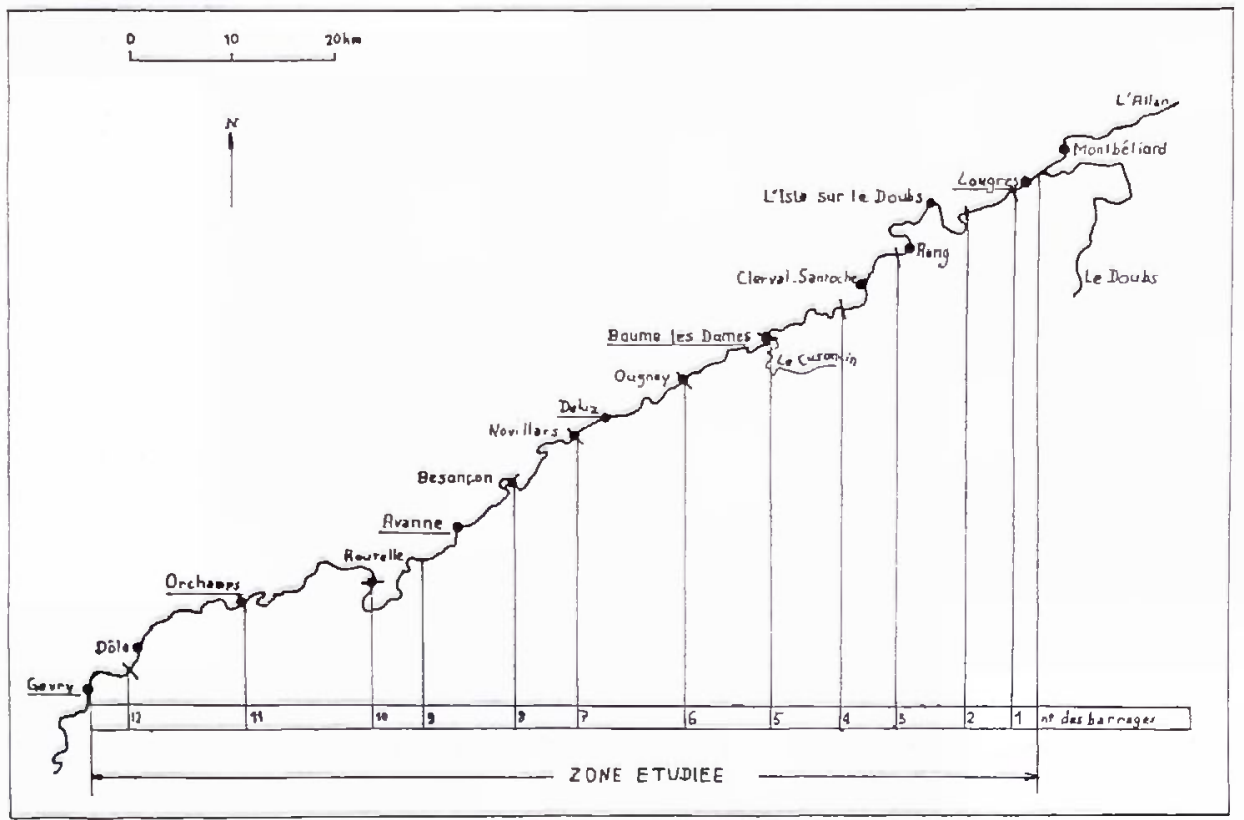

Fig. 1. - The lower Doubs. Area of the study. Sampling stations are underlined. The twelve numbered verticals give the location of the planned dams. 
"Save the Doubs" operation (operation Sauvetage du Doubs), with the aim of restoring the original character of the Doubs as a clean river, stocked with many species of fish.

A substantial number of cleansing operations were carried out. The originality (at the time) of the process followed was the design of system for auto-surveillance of the water quality both in the stream, in aout 10 permanent stations and in the discharges of the region's main polluters (in particular, two paper mills). The SRAE department of the Ministry of Agriculture has collected weekly data on water quality in the lower Doubs (downstream from Montbéliard) since 1977 at six measurement stations: Lougres, Baume-les-Dames, Deluz, Avanne, Orchamps and Gévry (figure 1). These are: temperature, dissolved oxygen, $\mathrm{BOD}_{5}, \mathrm{COD}$, chlorophyll a, dissolved mineral nitrogen in the form of $\mathrm{NH}_{4}, \mathrm{NO}_{2}, \mathrm{NO}_{3}$ : orthophosphate, $\mathrm{pH}$, and conductivity.

Another project, very different from the "Save the Doubs" operation, was launched for the construction of a canal larger than the existing one, to allow for the navigation of large boats between the Rhine and the Saône and, more generally, between the North Sea and the Mediterranean. Since this large canal and the Doubs must join at many points between Montbéliard and Dole, the development will alter the geometry and hydraulic characteristics of part of the Doubs : average depths will be increased and flow velocities reduced by the construction of twelve large dams with heads ranging from four to eleven meters. These heads are much greater than those of the numerous existing small dams, none of which exceed three meters.

The Regional Equipment Department of the Ministry of Transport assigned Electricite de France the task of designing a mathematical model to assess the effects of these changes in hydraulic characteristics on the thermal conditions prevalent in the Doubs, and on the river's dissolved oxygen balance between Montbéliard and Dole. A temperature-dissolved oxygen-BOD5 model was developed (Chalon et al, 1978) on the basis of the sparse data available at the time (dissolved oxygen, temperature and BOD5 data at Lougres and Avanne between 1969 and 1975). The results obtained indicated that BOD discharges by riverside establishments had to be reduced by $60 \%$ between Montbéliard and Dole to assure nearly the same concentrations of dissolved oxygen in the river after its development for heavy navigation as at present, and that this reduction was necessary for the minimum concentration in the section not to be below $3 \mathrm{mg} / \mathrm{l}$.

The Regional Equipment Department, conscious of the value of the data relating to water quality collected by the SRAE and of possible omissions in the dissolved oxygen balance model that had been developed, in particular regarding influence of primary growth on oxygen, requested that we devise a new numerical water quality model meeting the two requirements set out below : 
- to make an assessment of the present water quality of the Doubs river between Montbéliard and Dole as regards dissolved oxygen, BOD5, phytoplanktonic biomass, nitrogen and phosphorus (model variables).The data for 1981-1982 provided by the SRAE network, which was specially reinforced were used for this purpose. The additional system, managed by the CEMAGREF of the Ministry of Agriculture was used to acquire data on turbidity (Secchi depth), suspended solids, primary growth (C14) and the proportion of deteriorated pigmentation in chlorophyll a (active chlorophyll a is a phytoplankton biomass indicator)

- to provide a tool capable of predicting the main dissolved oxygen trends in the river in the event of the construction of the Rhine-Rhone canal catering for large tonnage navigation.

The approach followed in devising and checking the water quality model was as follows: analysis of the data collected by the SRAE and the CEMAGREF between May and October 1981 , a period of the year during which water quality problems arise; calibration of the model by end of 1981 on the basis of these data; a proposal of supplementary measurements for 1982 data, and finally verification of the validity of the model using data collected by the SRAE from January to October 1982.

\section{ANALYSIS OF DATA COLLECTED BETWEEN MAY AND OCTOBER 1981}

From a consultation of different firms self-monitoring records stored at the Service des Mines of Besançon, the files (list of polluters) of the Rhône Mediterranean basin Agency, and data stored by the Doubs Navigation Department, estimates were made of the average daily discharge of $\mathrm{BOD}_{5}$, nitrogen and phosphorus by industries and communes installed on the lower Doubs between Lougres and Gévry: 15 tons of $\mathrm{BOD}_{5}, 2$ tons of nitrogen (of which $30 \%$ in dissolved mineral form), and 0.4 tons of phosphorus (of which $50 \%$ in dissolved mineral form).

Measurements of water quality at Lougres, Baume, Deluz, Avanne, Orchamps and Gévry were analysed with a dual purpose in mind: firstly, to demonstrate the main water quality trends in relation to hydrological and meteorological conditions; secondly, to define quantitative relations between some water quality parameters, to be used in the numerical model to reduce the number of fitting parameters.

Under local meteorological conditions, the lower Doubs, whose average depth in about $2 \mathrm{~m}$ during low-water periods downstream from Montbéliard, is near its thermal equilibrium (refering to the atmospheric local conditions), with quite homogeneously distributed temperature in space. This is not true, however, in flood conditions. The 


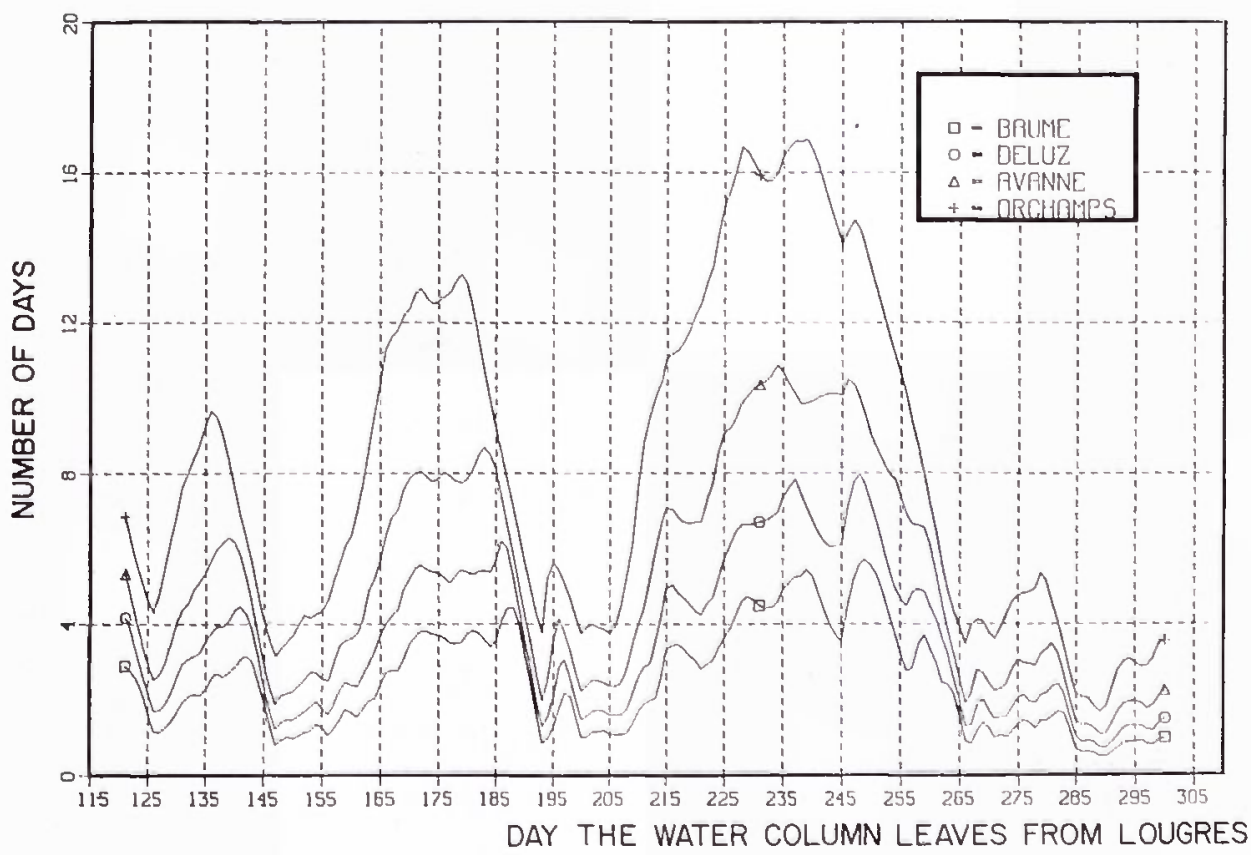

Fig. 2. Calculation of the mean hydraulic residence time between Lougres and different sampling stations (may-october 1981).

hydrological conditions of the river and geometrical data of the stream supplied by the Compagnie Nationale du Rhône (CNR) provide an estimate of residence time in the 170 kilometers Montbéliard-Gévry section of the river used for the calculation (figure 2) : a volume of water takes 15 days on average to flow through this section at a rate of flow of $25 \mathrm{~m}^{3} / \mathrm{s}$ at Besançon (average rate of flow in August, which had the lowest average monthly rate of flow in 1981).

The chlorophyll a concentration levels measured (up to $150 \mathrm{mg}$ chla per $\mathrm{m}^{3}$ ) prove that the catchment basin is enriched to a large extent in nutrients.

Similarity is observed between the trend over time of the parameter chlo- rophyll a and the profile of hydraulic residence time (comparison of figures 2 and 3). This underlines the determinant influence of the parameter representing residence time on phytoplankton dynamics in the river : the longer the residence time, the more time there is for phytoplanktonic growth. Comparison of the chlorophyll profile at Lougres with that of a station further downstream shows that the influence of residence time is undisputable : it may be observed that the longer the residence time, the greater the difference between the two profiles.

The dissolved oxygen content recorded over this length of time has always exceeded $5.5 \mathrm{mg} / \mathrm{l}$ (minimum recorded on september 2nd in early 


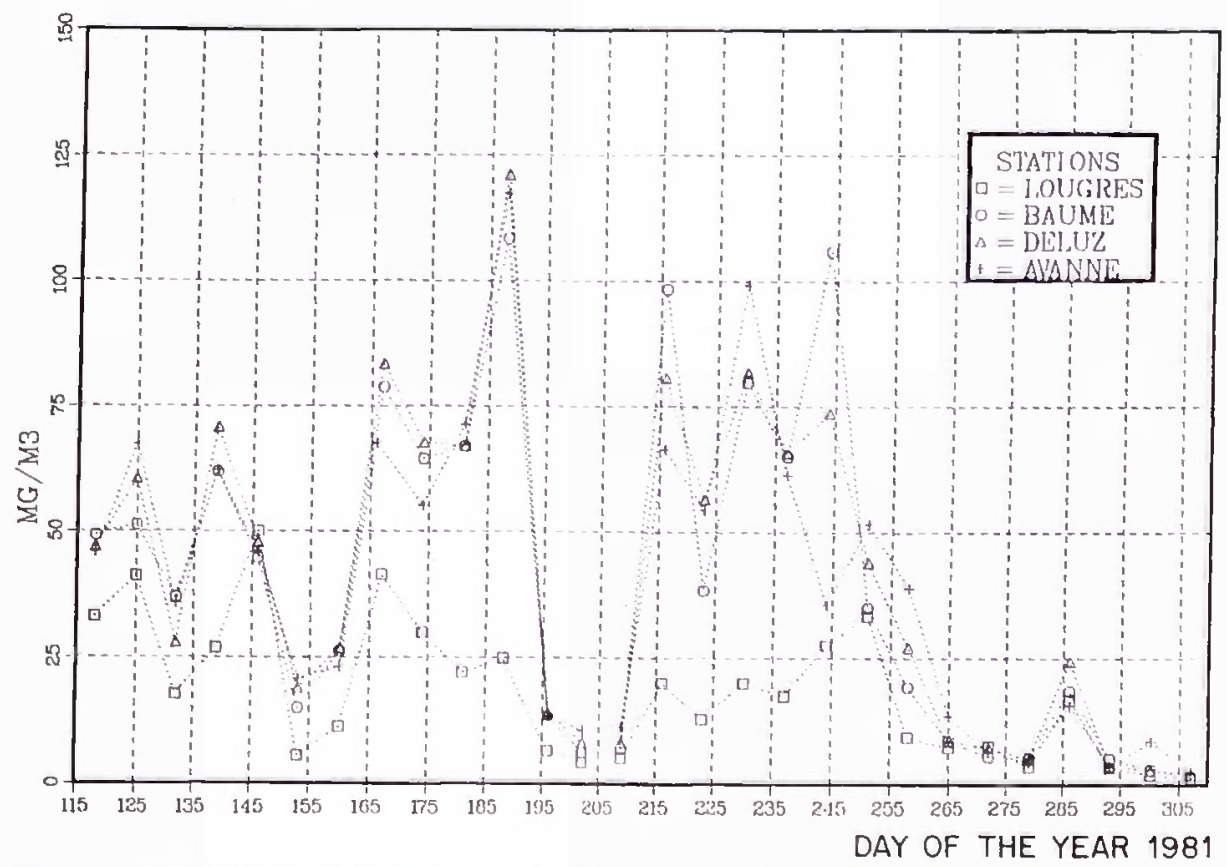

Fig. 3. - Total chlorophyll a measurements. High concentrations are observed for long hydraulic residence time.

morning at Orchamps). From an ecological point of view, this level is deemed acceptable. During sunny days, and low water periods, dissolved oxygen content displays a large diurnal amplitude (increase of $6 \mathrm{mg} / \mathrm{l}$ between dawn and evening, with oxygen saturation rates nearing $200 \%$ at the end of the afternoon) in relation to the photosynthetic growth of planktonic algae. Thus, at certain times the stream is permanently over-saturated (day an night) for several days (especially between the $12^{\text {th }}$ and the $18^{\text {th }}$ of August according to a continuous measurement recording station which was temporarily installed in running water at Deluz).

The influence of phytoplankton on the dissolved oxygen balance of the downstream section of the Doubs is quite substantial in the summer, which shows that a model portraying the dissolved oxygen content with only three variables (temperature, dissolved oxygen, BOD) for this stream would be unrealistic. Phytoplankton also acts on the nitrate nitrogen profiles (the effect is not so perceptible on phosphorus, which is very abundant) since nitrate concentrations are the lower, the higher biomass levels recorded. However, nitrate concentrations are never so low as to limit algal growth, except perhaps, at end-August downstream from the section under consideration (figure 4).

The quantitative statistical relations disclosed by the measurements of water quality are recalled below. The 


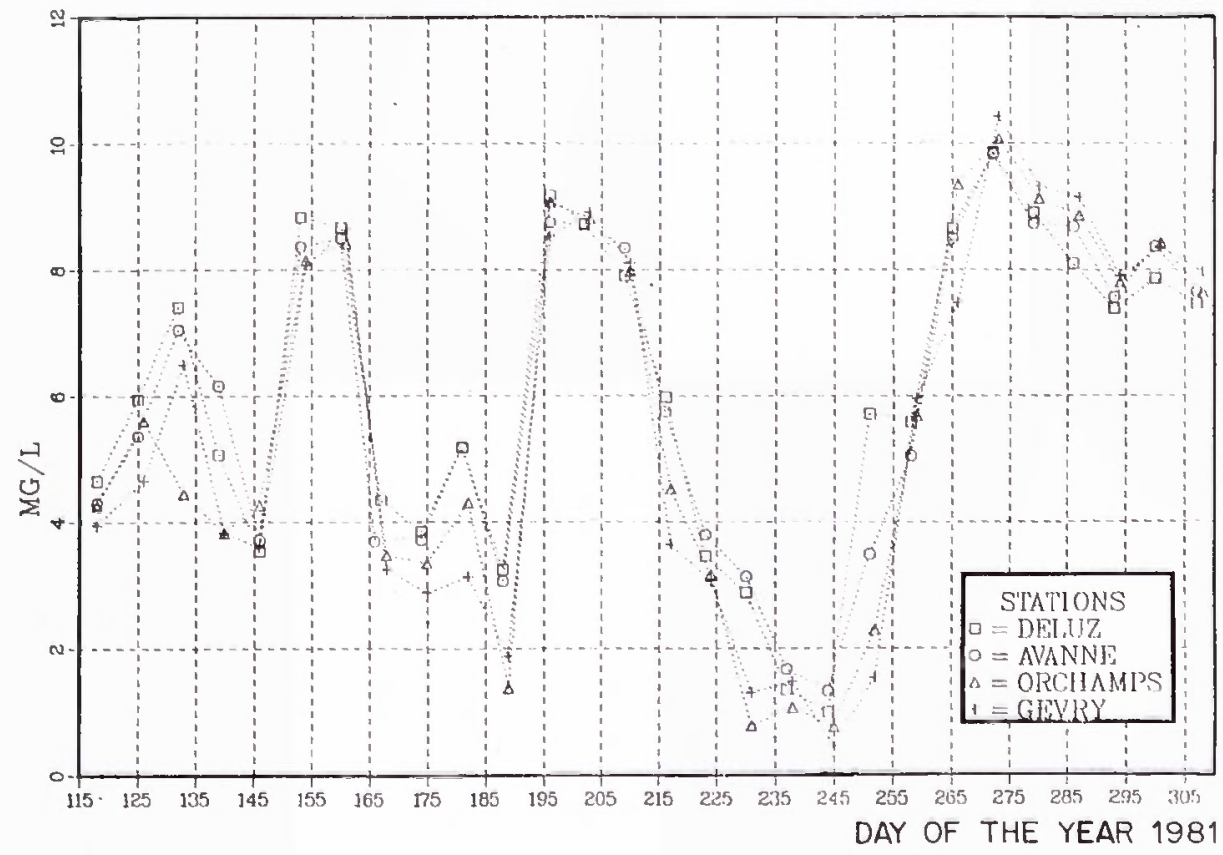

Fig. 4. - Nitrate measurements. The low values are associated with high chlorophyll a values.

correlation study of chlorophyll a content and Secchi depth, whose aim is to integrate the role of phytoplankton in attenuating solar radiation, defines two parameters of the model: the light extinction coefficient $k^{\prime} e$ of solar radiation in water without live phytoplankton, and $B$, the light attenuation constant due to algae (see table 1). The comparison of measurements of chlorophyll a and $\mathrm{BOD}_{5}$ concentrations leads to the relation :

$$
\text { f. }\left(1-e^{-5} K_{4,20}\right) \simeq 0.04 \text {, }
$$

where $K_{4,20}$ is the respiration rate of algae and $f$ is the volume of oxygen produced'to synthesize a phytoplankton weight unit expressed in terms of chlorophyll a. This relation is obtained by taking a simple model simulating the uptake of dissolved oxygen in a
BOD5 experiment (Gosse 198la) and by considering the statistical relation observed at each measurement station :

$$
\mathrm{BOD}_{5}=0.04 \times \text { (chla) }+\mathrm{M}
$$

where (chla) is the chla concentration in $\mathrm{mg}$ per $\mathrm{m}^{3}$ and $\mathrm{M}$ a constant (varying from one station to the next), which is proportional to the average of inert oxidizable pollutants conveyed by the river.

The statistical relations $\left(r^{2}=0.8\right)$ between DCO and chlorophyll a measurements are :

COD $=0.1$ (chla) $+\mathrm{N}$, where $\mathrm{N}$ is a constant (which varies from one station to the next) proportional to the average level of inert oxidizable substance conveyed by the river. It may be considered that the constant 0.1 

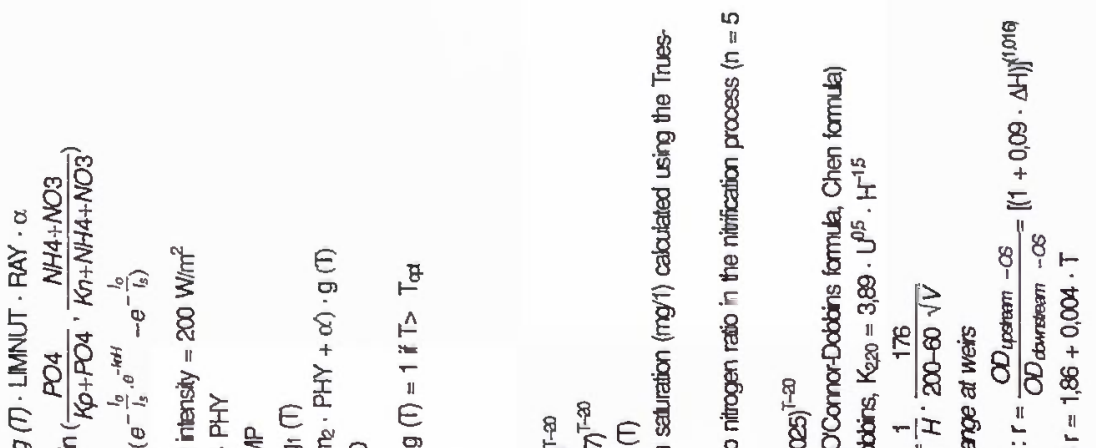

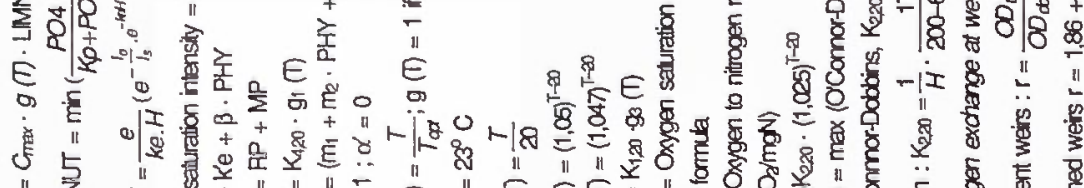

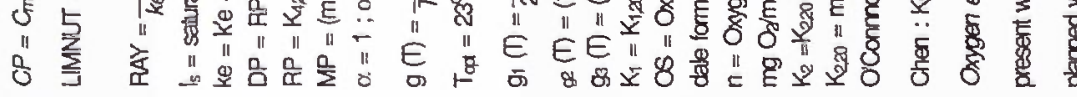

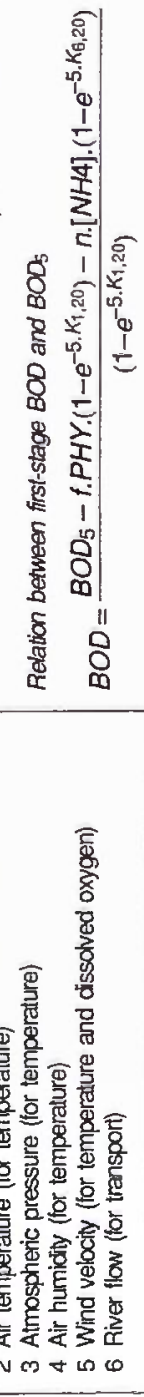


is a good approximation of $f$, providing that inert oxidizable pollution does not vary too much over time at a given point on the river. It can be observed that $\mathrm{M}$ and $\mathrm{N}$ follow a similar trend in space (growth between Lougres and Avanne, decline between Avanne and Gévry), which makes the region between Deluz and Avanne the section of the Doubs most heavily laden with oxidizable pollutants, which meets the earlier estimate of contributions of the catchment basin.

The comparison of measurements of chlorophyll a content (LORENZEN method) with those obtained with the SCOR-UNESCO method shows that the mean percentage of non-deteriorated chlorophyll a (therefore corresponding to Phytoplanktonic biomass) is approximately $80 \%$ of the total chlorophyll a concentration. This percentage is used in the model to compare its results relating to phytoplanktonic biomass with the measurements of total chlorophyll a concentration. The analysis of measurements of TSS (total suspended solids) and their comparison with chlorophyll a concentrations indicate that the intracellular algal ratio $\mathrm{C} / \mathrm{chla}$ is below 100 . Finally, an estimation of $C$ max (maximum growth rate of algae) of Cmax is derived from the analysis of measurements of primary growth :

$$
C \max \simeq 6 . \log \left(1+\frac{40}{C / c h l a}\right) .
$$

It is only an approximate one because of the difficulties of interpretation of a measurement of the production of carbon 14.

\section{CALIBRATION OF THE MODEL}

Based on the simulation of the dissolved oxygen balance and the eutrophication of the stream, the model simulates nine variables between Lougres and Gévry: temperature, dissolved oxygen, BOD, phytoplankton (expressed in terms of chlorophyll a), phosphorus and nitrogen taking a form which cannot be assimilated by algae, orthophosphate, ammonium and nitrate (three elements which are assimilated by algae). Figure 5 provides a schematic portrayal of the ecosystem modelled.

The model is one-dimensional: it assumes that the water quality calculated at one point represents the average over the corresponding transversal section. Longitudinal dispersion is neglected. The water columns thus only move upstream to downstream by advection associated with the rate of flow of the river.

The distribution of the variables over time entered into the model at Lougres - i.e. upstream limit conditions - is defined on the basis of weekly sets of measurements available at that station, by linear interpolation of the values within the interva Is for which there are no measurements. Two values of dissolved oxygen concentration were recorded at Lougres on measurement days: one measurement over an average 24 hours sample, one measurement at the end of the afternoon. The two values allow the daily cycles of dissolved oxygen to be drawn and incorporated into the upstream sec- 
Ph. Gosse

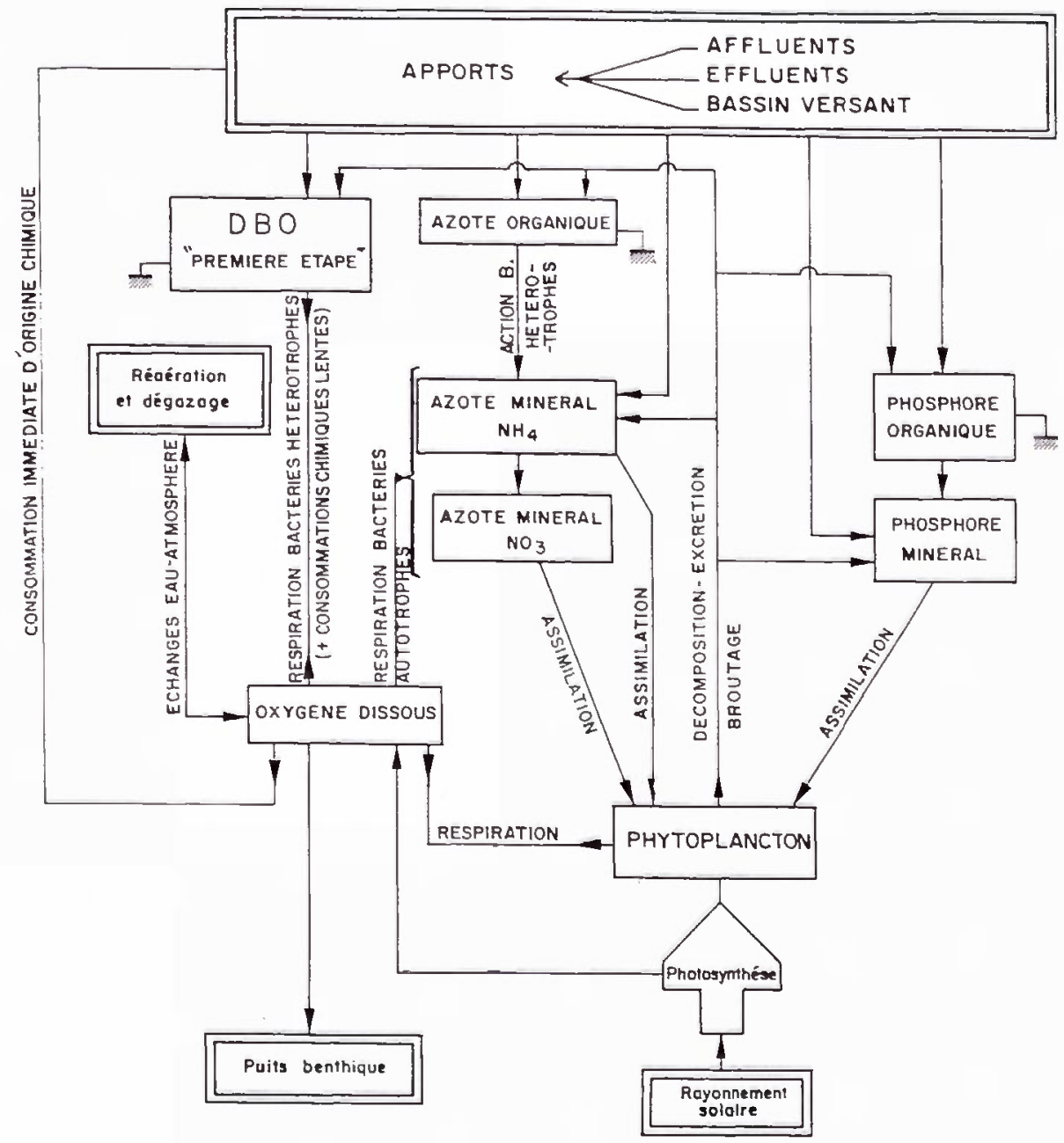

Fig. 5. - Flow diagram of the model. Temperature which acts on most of the mechanisms is not represented on this diagram.

tion of the model (sinusoidal function). The variables representing non-assimilable nitrogen and phosphorus for which there are no measurements are assumed to have at Lougres the same values as dissolved mineral nitrogen and orthophosphate respectively.

The model which is fundamentally unsteady takes account of the varia- bility of the rate of flow and meteorological parameters. By contrast, the fluxes of the BOD, nitrogen and phosphorus discharges by riverside establishments along the section of river used for the calculation are assumed to be independent of time.

The numerical solving method adopted is identical to the method applied to the Loire (Gosse 198lb): the 
time-step for the calculation is fixed (three hours) and the consideration of fourteen fixed-length sections (35 in the case of simulation of the construction of the large canal with a hourly time step in that case) which are traversed over a variable number of time-steps, depending on the rate of flow of the stream, allows substantial discontinuities to be taken into account (major pollutant discharges, changes in hydraulic characteristics, discontinuity of dissolved oxygen concentration of large dams).

The results of the calculations are compared with data at different locations (Baume, Deluz, Avanne, Orchamps and Gévry stations).

Table I presents the mass balance equations of the different variables. The now-conventional expression for temperature (Gras, 1969; Poulin, 1982, Jacquet, 1983) does not appear here. The forcing functions of the model are also recapitulated in Table 1.

Since the parameter $\mathrm{BOD}_{5}$ not only takes into account oxydizable discharges by riverside polluters but also organic pollution due to vegetation (endogeneous respiration and respiration of bacteria deteriorating detritic vegetation), it is not directly simulated but consists of a combination of three variables (see equation in table 1) : first stage BOD (called first stage because it does not include nitrification mechanisms - transition from $\mathrm{NH}_{4}$ to $\mathrm{NO}_{3}$ - taking placein the $\mathrm{BOD}_{5}$ test), ammonium nitrogen and phytoplankton. The equation combining those three variables of the model and $\mathrm{BOD}_{5}$ is used : 1) as an input to the model to define the upstream boun- daries of the variable first stage BOD, 2) at the downstream measurement stations to allow the comparison of $\mathrm{BOD}_{5}$ data with the value of this parameter determined from the model.

The difficulty in calibrating the model stems from the interdependence of variables, i.e, the appearance of some adjustment parameters (coefficients) in the balance equations of two or several variables. The calibration of the model (excluding temperature) is thus envisaged in two steps so as to overcome this problem: setting the parameters of a first version of the model simulating all the variables but only calibrating the evolution of the three master variables i.e, first the variable which is at the heart of the study, namely dissolved oxygen; and second, the variables which have a major influence on modeling of the preceding one, here the first stage $B O D$ and phytoplankton*.

A second version of the model, the final version, is then calibrated by refining the choice of the parameters of the preceding version by taking into account the fitting of the parameters relating to the five remaining variables.

The variables $\mathrm{NH}_{4}, \mathrm{NO}_{3}, \mathrm{PO}_{4}, \mathrm{NOR}$ and POR are not calibrated in the first version: the effect of nitrification (transformation of $\mathrm{NH}_{4}$ into $\mathrm{NO}_{3}$ ) turns out to be a second order quantity in the dissolved oxygen balance; further, phosphorus and nitrogen nutrients have no limiting effect on algal growth over the period under study. The values of some parameters of the model representing the balance of these secondary variables and which also appear in the balance of the three master variables are arbitrarily chosen in the first model : $\left(\mathrm{f}_{\mathrm{N}}=0,003: \delta_{\mathrm{N}}=0,5\right.$; $\left.K_{5,20}=0,05 ; K_{6,20} ; 0.3 ; \eta=0.3\right)$. 
In general, the parameters of the model are fitted using the method of least squares. This method is applied to each variable, considering the measurements stations as a whole.

\subsection{First calibration}

The first version of the model is calibrated as follows: one first adjusts the value of the parameters of the model appearing in the mass balance of the variable which is least dependent on the other two (here, phytoplankton). Then in growing order of dependance, the parameters which have not yet been defined and appear in the balance of the variable $\mathrm{BOD}$ are adjusted. Finally, in the light of the parameter choices already made, one examines whether or not it is possible to accurately model the dissolved oxygen variable, which is the most dependent in the system. Poor modeling of this variable should of course lead to review of the earlier choices of parameter values.

a) Phytoplankton biomass

In assessing the mass balance of the phytoplanktonic biomass, it is assumed that the water is not toxic ( $\alpha$ $=1$ and $\alpha^{\prime}=0$ ). The algal growth rate is classically assumed to depend (multiplicatively) only on three factors: solar radiation (the Steele formula), nutrient availability (which, considering the abundance of nutrients, does not act much in the system, taking $\mathrm{Kp}$ $=0,01 \mathrm{mg} \mathrm{PO} 4 / \mathrm{l}$ and $\mathrm{Kn}=0.03 \mathrm{mg}$ $\mathrm{N} / \mathrm{I}$ as half-saturation constants of phosphorus and nitrogen) and temperature (linear law for $\mathrm{T}$ lower than $23^{\circ} \mathrm{C}$ ). $\mathrm{DP}$, the rate of loss of algae is divided into two terms: one repre- senting respiration - which is a linear function of temperature - corresponding to the loss of cellular weight causing an almost immediate dissolved oxygen uptake $(K 4,20 . T)$ : and the second term (MP) comprising mortality, predation and sedimentation processes and which constitutes an addition of BOD, is assumed to be a linear function of temperature. For a given temperature MP is equivalent to the sum of a constant portraying the behaviour of an isolated cell and a term, proportional to biomass concentration, portraying the behaviour of a large population (over-population, predation).

Since some parameters of the mass balance of phytoplankton are determined by analysing measurements (non-algal turbidity, self-shading, see chapter 2) or are considered to be known because they do not play a dominant role in the results of the model (the value of IS or the solar radiation saturation intensity corresponding to that calculated for the Seine by Bordet, half-saturation constants for phosphorus and nitrogen), the calibration of the phytoplanktonic model reduces to the fitting of three parameters: Cmax (maximum growth rate), $\mathrm{m} 1+\mathrm{K} 4.20$ (loss term portraying the behaviour of one cell), $m_{2}$ (loss term relating to algal density). Regardless of the values of the other two parameters, the minimum deviation between calculation and measurements is secured for Cmax higher than or equal to 2 day $^{-1}$, but this difference is not much reduced for Cmax exceeding 2. The latter value is adopted as the most plausible in the light of the literature : hence, 
for $m_{1}+K_{4,20}=0.15^{*}$, the most appropriate value of $\mathrm{m}_{2}$ is 0.003 .

\section{b) First stage $B O D$}

Since phytoplanktonic biomass is quite accurately modeled, attention can be directed to setting the parameters of the model which appear in the balance of the first stage $B O D$, by comparing $\mathrm{BOD}_{5}$ measurements with $\mathrm{BOD}_{5}$ values calculated by the model. Given the mathematical formalisation, the calibration of the $\mathrm{BOD}$ model reduces to setting three parameters: $f$ (chlorophyll to oxygen ratio), $\mathrm{K}_{1.20}$ (decay rate of $\mathrm{BOD}$ at $20^{\circ} \mathrm{C}$ ) and $\mathrm{SED}_{3}$ (velocity of sedimentation of BOD). If the value $f=0.1 \mathrm{mg} 0_{2} / \mu$ chla (originating from the correlation of chlorophyll and COD studied in the analysis of measurements, see chapter 2) is accepted, the choice of a constant value for $K_{1,20}$ leads to adopting for SED3 an increasing upstream to downstream linear function, which is supposed to represent the growing predominance of dead phytoplankton in the BOD as one moves further downstream. The choice of $K_{1.20}=0.25$ day $^{-1}$, which is currently accepted in the literature leads to the selection of a value for SED3 between $0.05 \mathrm{~m} /$ day upstream and 0.15 $\mathrm{m} /$ day at the extreme downstream boundary of the section examined.

\section{again \\ c) dissolved oxygen, and BOD}

Since phytoplankton biomass and $\mathrm{BOD}$ are quite accurately modeled,

a value below 0.15 of the $m_{t}+K_{4,20}$ sum improves the quality of fit but this value 0.15 is only temporarily adopted, since $K_{4,20}$, whose value is non-zero can only be set by considering the dissolved oxygen balance. attention is finally focused on dissolved oxygen.

The exchanges between the water and the air at the surface of the river (determination of K2) are portrayed in the dissolved oxygen balance by taking the larger value given by one of two formulae : one is the O'Connor and Dobbins formula (the hydraulic characteristics of the Doubs are quite similar to those considered in the experiments undertaken by these authors) and the other, the Chen formula (valid for stagnant water and taking windspeed into account) (Gosse, Albignat, Coantic, 1983). The oxygenation of the heads of small dams is modeled by Gameson's formula. If, in addition a benthic oxygen demand of $0.5 \mathrm{~g}^{\mathrm{m}} \mathrm{m}^{-2}$. day ${ }^{-1}$ at $20^{\circ} \mathrm{C}$ is taken for the whole section examined (estimated by a local model at Deluz in the course of a specific study), the model clearly tends to generally underestimate the diurnal production of oxygen by photosynthesis and therefore diurnal dissolved oxygen amplitudes.

The value $f=0.1$ thus seems a bit low. Notwithstanding, on the basis of Sverdrup's (1942) or Golterman's (1975) equations for analysing photosynthesis mechanisms schematically, $f$ should be equal respectively to $0.0039 \mathrm{C} / \mathrm{chla}$ and $0.0027 \mathrm{C} / \mathrm{chla}$. Bearing in mind that the ratio $\mathrm{C} / \mathrm{chla}$ is usually of the order of 40 to 50 , it would then seem more realistic to take $f=0.15$, since this can markedly improve the representation of daily dissolved oxygen cycles. It can be observed that the choice of $f=0.15$ also determines the value of $K_{4,20}$ (i.e 0.06 day $^{-1}$ ) through the relation between 
these two parameters ascertained in the analysis of the measurements made (see table 1).

Increasing the value of $f$ in the model indeed increases photosynthetic oxygen production, but at the same time more organic pollution is produced by dead phytoplankton (rate proportional to f). Thus, to secure an accurate estimate of $B O D$, it is necessary to change the values of SED3 and $K_{1.20}$. Having set the two parameters by studying the differences between calculated and measured values at successive stations moving downstream and assuming $\mathrm{K}_{1,20}$ constant over the whole section, the most accurate values seem to be $\mathrm{K}_{1,20}=0.35$ day $^{-1}$ and SED3 varying from $0.1 \mathrm{~m} /$ day in the upstream section to $0.6 \mathrm{~m} /$ day downstream. Scaling of the dissolved oxygen variable confirms the suitability of choosing $\mathrm{K}_{1,20}=0.35$ (albeit deviations from the measured values remain in the afternoon during very sunny days when there is a low rate of flow) providing benthic demand increases regularly from 0.2 at Lougres, upstream to 2.5 g. $\mathrm{m}^{-2}$.day ${ }^{-1}$ at Gévry downstream. This choice is in a sense equivalent to a downstream increase in oxydizable pollution deposits due both to the decline in the slope of the bed and the increase in particular detritus (especially dead algae) in the total $B O D$ as one moves down the river.

It may nevertheless be observed that the hypothesis (not adopted) of an increased in $K_{1,20}$ upstream to downstream is mathematically plausible. However, it is more difficult to justify without measurements.

\subsection{Second calibration}

At this stage, the final version of the model is established simulating all the variables as closely as possible, (figures $6,7,8$ ).

As regards the phytoplankton balance equation, we have seen that the lower the value of $m_{1}+K_{4,20}$, the better the fit of the chlorophyll variable. $m_{1}=0$ is thus taken (the value of $K_{4,20}$ equal to 0.06 follows from the value of f). The best fit of the phytoplanktonic model is then obtained with $\mathrm{m}_{2}=0.004$.

Assuming that $\delta \mathrm{N}$ is maintained at $0.5(\delta \mathrm{N}=$ percentage of nitrogen in dead phytoplankton which can almost immediately be assimilated by live phytoplankton) $K_{5.20}=0.05$ day $^{-1}$ (speed of mineralisation of nitrogen) and that $\eta=\frac{\mathrm{NH} 4}{\mathrm{NH} 4+\mathrm{NO} 3}$ (reflecting the non preferential effect of ammonium nitrogen over nitrate nitrogen in the food supply of algae) modeling of the nitrogen cycle yields the following optimum choice defined by comparing with the measurements the spatial evolution of the ammonium and nitrate nitrogen variables :

$\mathrm{K}_{6,20}=0.35$ day $^{-1}$ (nitrification rate) and $f_{\mathrm{N}}=0.0035 \mathrm{mg} \mathrm{N} / \mathrm{\mu g}$ chla (proportion of nitrogen in algal cells). These changes do not greatly alter the balance of BOD and dissolved oxygen variables, and so do not induce any significant changes in the parameters which have already been optimized ( $K_{1}$, SED3, BEN).

Scaling of the orthophosphate variable leads to the choice of $\mathrm{fp}=$ $0.0025 \mathrm{mg} \mathrm{PO} 4 / \mu \mathrm{g}$ chla (proportion of phosphorus in algal cells) if $\delta p=0,5$ 
is taken (percentage of phosphorus in dead phytoplankton which is found directly in mineral form) and assuming $\mathrm{K}_{3.20}=0.05$ day $^{-1}$ (mineralisation rate of Phosphorus assumed to be equal to that of nitrogen).

It is of interest to observe that, according to the Sverdrup equation schematising algal metabolism, the optimized value $f_{\mathrm{N}}=0.0035$ means that the cells have a $3 \%$ nitrogen content, further assuming a ratio C/chla of 50 and an intracellular carbon content of $40 \%$. Similarly, $f_{p}=$ 0.0025 means that the cells have a $0.6 \%$ phosphorus content. These two percentages and the ratio N/P are quite plausible.

\subsection{Main results of the model and problems raised}

The model provides an acceptable evaluation of chlorophyll a concentrations with the setting of only a limited number of parameters. The respective effects of the rate of flow, solar radiation and temperature on the trend of phytoplankton in space and over time can be distinguished: when the rate of flow of the stream exceeds 100 $\mathrm{m}^{3} / \mathrm{s}$ in the lower Doubs, phytoplankton does not have time to grow, its residence time in water being too short; there is consequently no significant population growth as one moves downstream. By contrast, in the dry periods (rates of flow less than $70 \mathrm{~m}^{3} / \mathrm{s}$ over at the least one week) residence times become quite long,

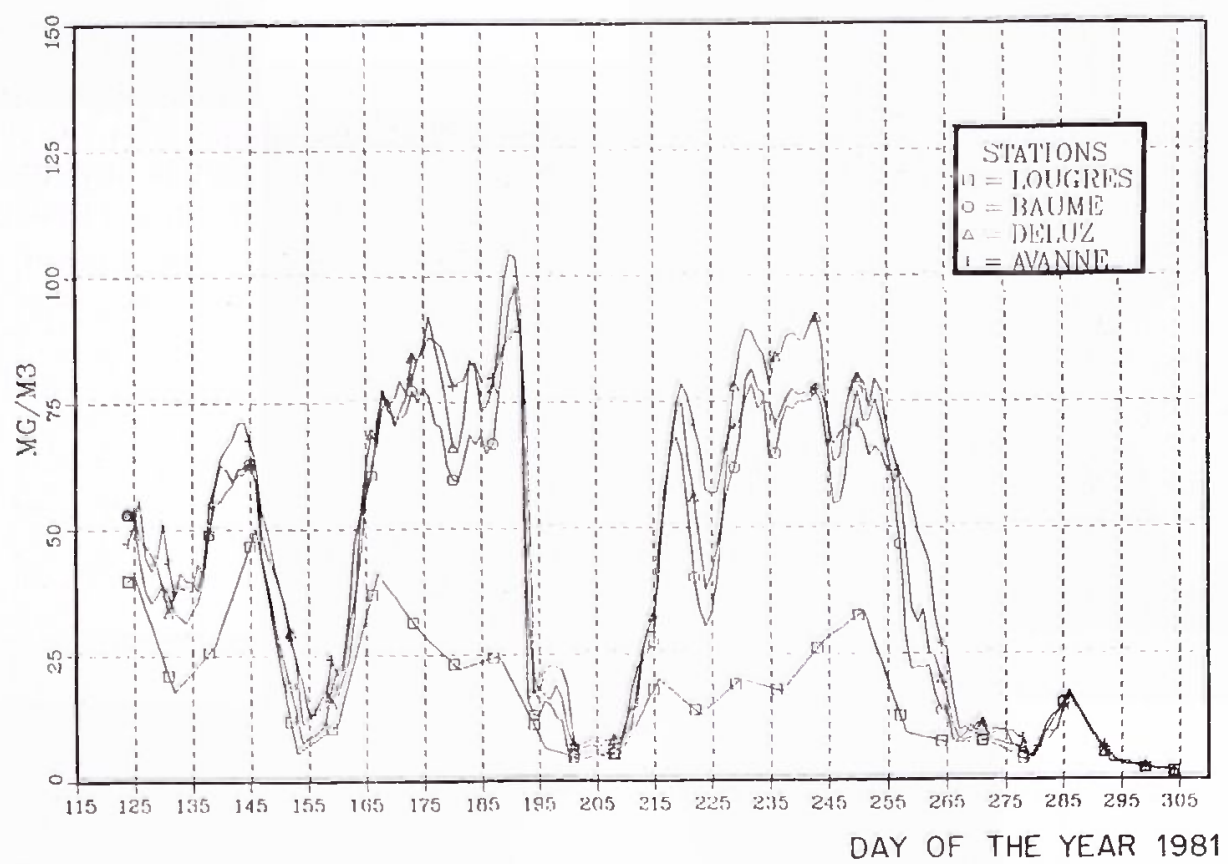

Fig. 6. - Calibration phase. Chlorophyll a calculated by the model in 3 stations downstream from Lougres. 


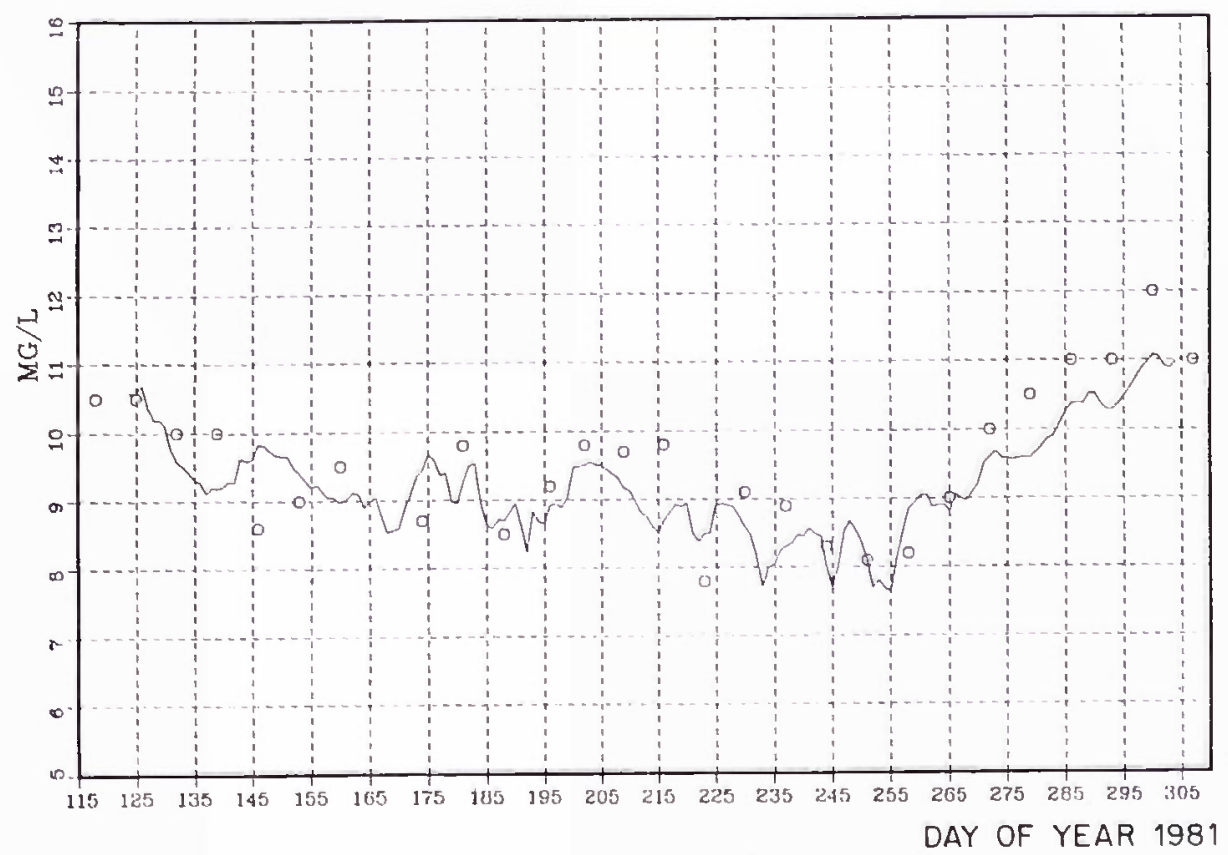

Fig. 7. - Calibration phase : Comparison of modeled and measured dissolved oxygen concentrations at Avanne at 7 a.m. GMT.

which favours substantial algal hine and (consequently) high water growth. These dry spells are generally temperatures which both intensify the accompanied by long periods of suns- effect of residence time in increasing

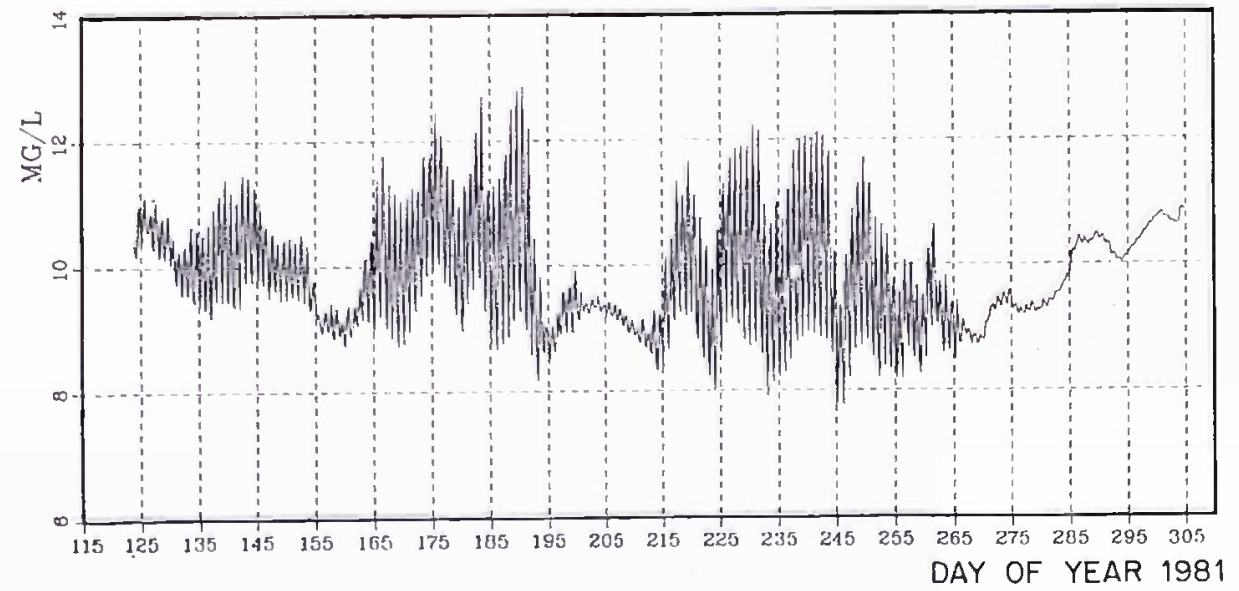

Fig.8 - Calibration phase - Field of variation of dissolved oxygen calculated by the model at Orchamps (which reveals the important diurnal variations in the model). 
concentrations of phytoplankton biomass. The same-direction effect of these three factors* explains the maximum chlorophyll a concentration obtained on July $9^{\text {th }}, 1981$ (over 125 $\mathrm{mg} \mathrm{chla} / \mathrm{m}^{3}$, daily average at Orchamps).

It should be noted that due to their abundance in the water, nitrogen and phosphorus have no limiting effect on algal growth except to a very slight extent at the end of August (owing to nitrogen depletion).

Dissolved oxygen is quite accurately simulated both as a daily average and for its diurnal cycle, although the peak of oxygen at the end of the afternoon of some very sunny days is not always well reproduced. The model gives a quantitative estimate of the role played by the different processes acting in the dissolved oxygen balance. This estimate confirms the extreme importance of planktonic vegetation (table 2).

Despite the quite rudimentary hypotheses regarding pollution discharges from the catchment basin, the simulations of the variables $\mathrm{BOD}_{5}$, nitrate nitrogen, ammonium nitrogen and orthophosphate are quite accurate; the calculated results of the latter two are more affected by the choice of hypothesis. The major role played by phytoplankton in trends for these variables can be clearly distinguished: very frequently, more than $50 \%$ of BOD5 is associated with algal activity

(although limited in a canalised river as in the present case, water depth is a fourth factor: reduced depth stemming from the reduced flow will increase the average irradiation of the water column by solar rays, thus making it more productive). (endogeneous respiration and respiration of bacteria deteriorating dead phytoplankton); and the low concentrations of nitrate nitrogen observed at the end of August are reasonably well explained by phytoplanktonic growth.

On completion of this phase (end of 1981), the proposal was made to consider for 1982 the additional measurements set out below to refine and improve the verification of the model: Kjeldhal nitrogen (to check the NOR variable and the estimate of nitrification), silicium, to check that it has no influence on algal dynamics (which is probable), zooplankton, to check that concentrations are always low and have a small effect on algal dynamics, and finally, a quantitative estimate of the fixed vegetation at several points of the stream to examine the extend to which it could, under certain circumstances, influence the dissolved oxygen balance, especially when there is a low rate of flow.

It was not possible to collect all these data in 1982 because of the workload of the organisations concerned. Zooplankton alone was measured, revealing its very low concentration in the Doubs (less than ten animals per litre). Fixed vegetation coverage was estimated, but this was inadequate to quantify biomass levels.

\section{VERIFICATION OF THE MODEL}

Calibrated on the basis of the data for May-October 1981, the model was verified using the data bases for Janua- 
Table 2 : Results of the model. Dissolved oxygen balance of the Doubs from Lougres to Dole. Main processes responsible for the generation or loss of dissolved oxygen in the river from may to september 1981.

\begin{tabular}{|c|c|}
\hline $\begin{array}{l}\text { Volume of dissolved oxygen which } \\
\text { appeared in the poubs between Lougres } \\
\text { and Dole from nay to september } 1981 \text { by : }\end{array}$ & $\ln 10^{3} \times$ tons \\
\hline Plutusynthes is & +13 \\
\hline Algal respiration & -2 \\
\hline $\begin{array}{l}\text { Respiration of heterotrophic bacteria } \\
+ \text { chemical demand in the water }\end{array}$ & -8 \\
\hline Nitrification & -1 \\
\hline Benthic demand & -2 \\
\hline $\begin{array}{l}\text { Gascous exelianges between the water and the } \\
\text { atmosphere when the water is undersaturated } \\
\text { with oxygen }\end{array}$ & +3 \\
\hline $\begin{array}{l}\text { Gaseous exchange between the water and the } \\
\text { atmosphere when the water is oversaturated } \\
\text { in oxygen }\end{array}$ & -3 \\
\hline Total & $+0,1$ \\
\hline
\end{tabular}

ry-October 1982 and January-April 1981.

The numerical values of the parameters of the models were of course maintained. The only model inputs to be changed were the quality of water in the Doubs at Lougres (limit conditions) as well as hydrological and meteorological conditions.
The overall results are satisfactory, considering the schematic nature of the model and the representativity and the uncertainity affecting the measurements (see figure 9). The main weaknesses of the model stem from the hypothesis concerning $\mathrm{NH}_{4}$ and orthophosphate discharges from the catchment basin, an assumption which is difficult to improve on consi- 


\section{Dissolved oxygen}

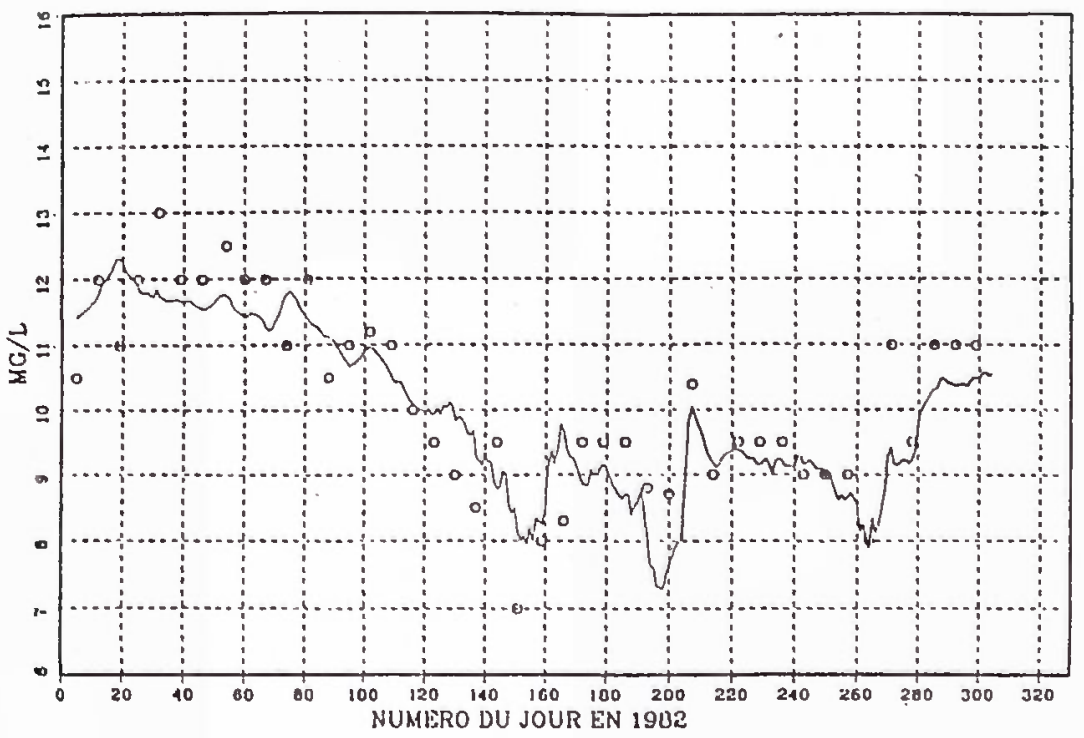

\section{BOD5}

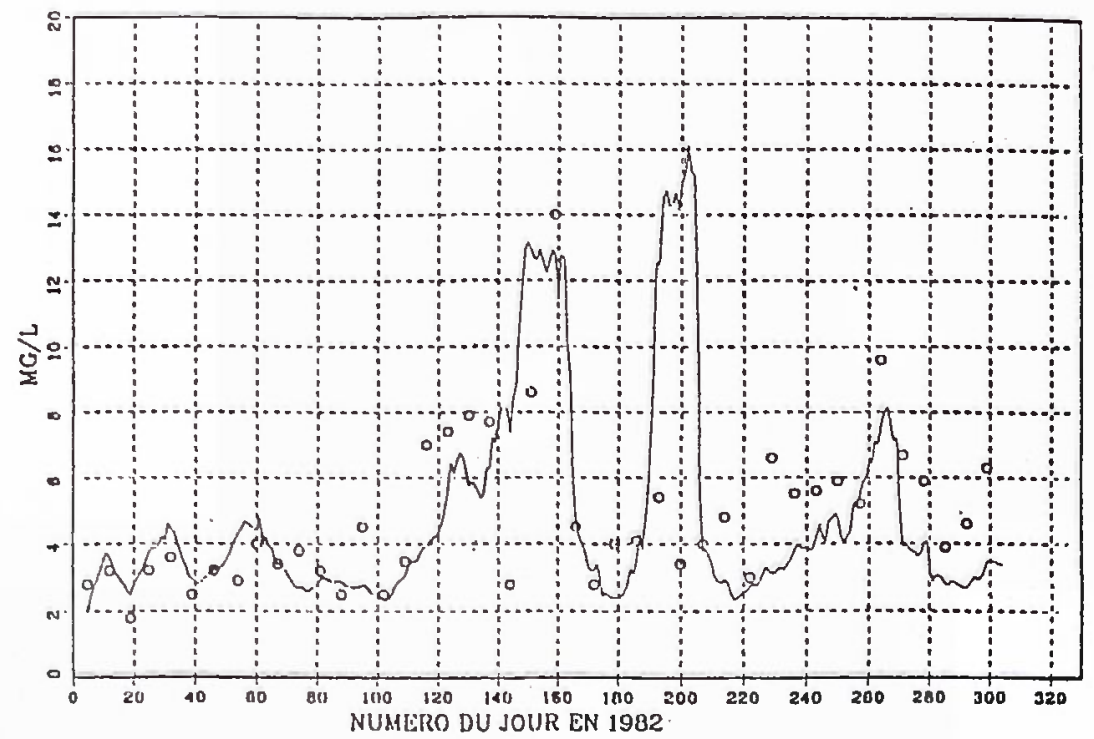

Fig. 9a. - Verification phase of the model in 1982. Comparison of calculations-measurements results at Avanne, for dissolved oxygen (mg/) and $\mathrm{BOD}_{5}$ (mg/l). 
Total chlorophyll a

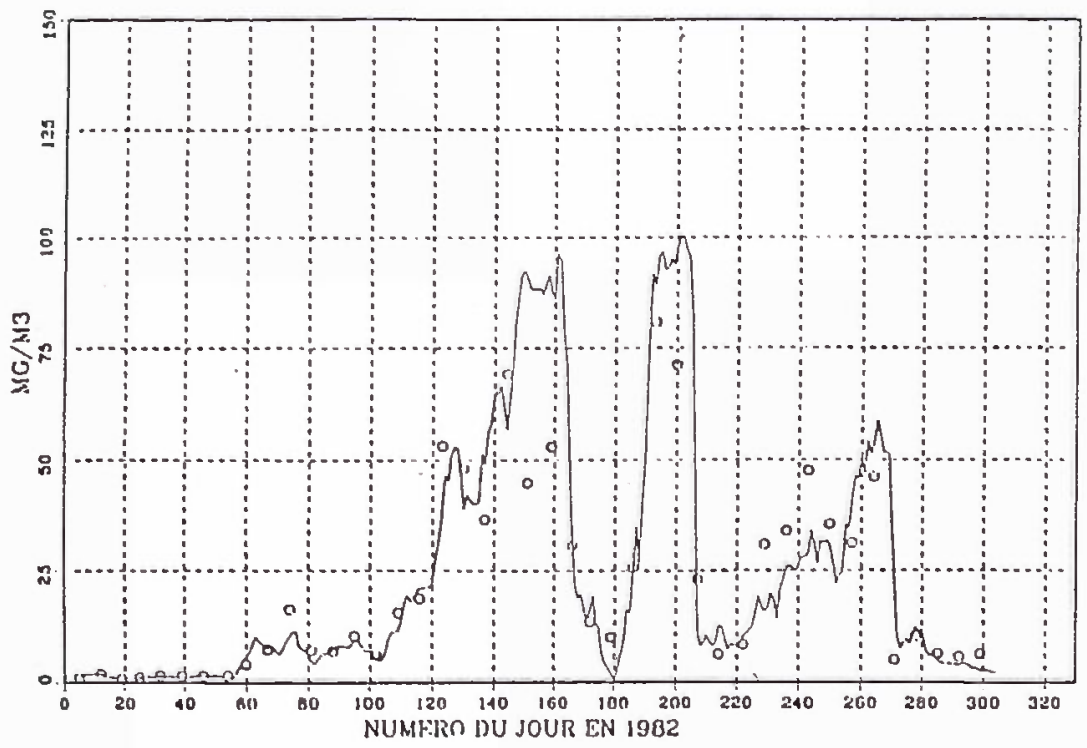

NO3

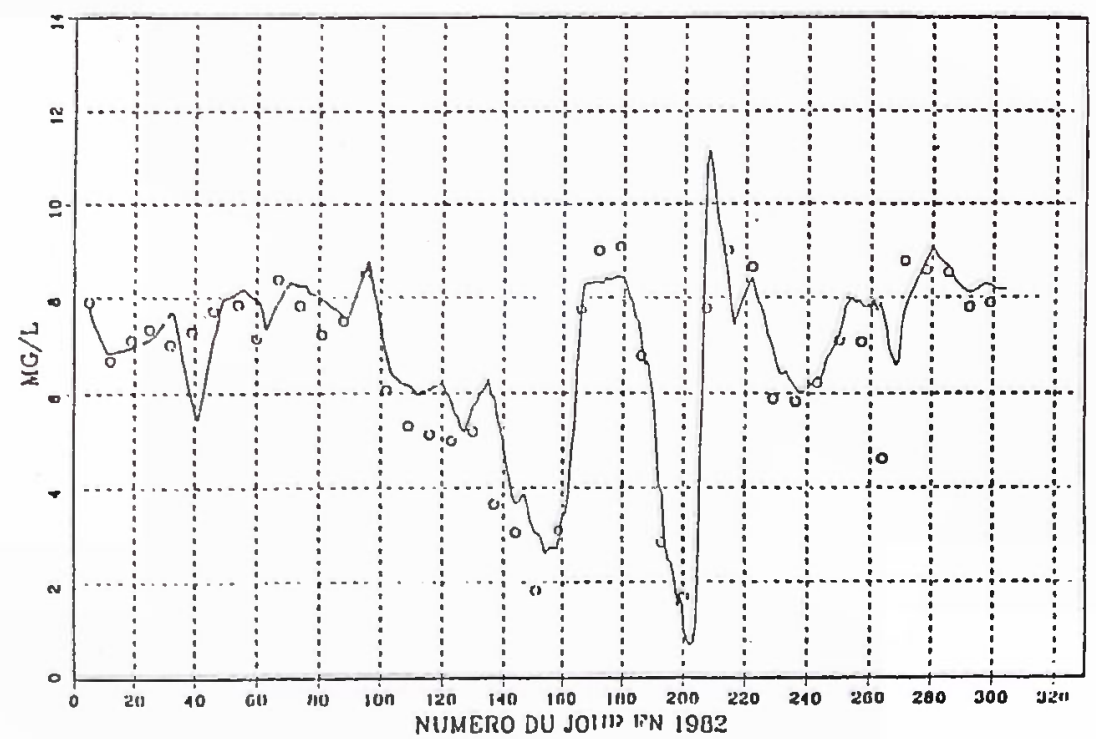

Fig. 9b. - Verification phase of the model in 1982. Comparison of calculations-measurements results at Avanne for chlorophyll a $\left(\mathrm{mg} / \mathrm{m}^{3}\right)$ and nitrate ( $\mathrm{mg} \mathrm{N} /$ ). 


\section{NH4}

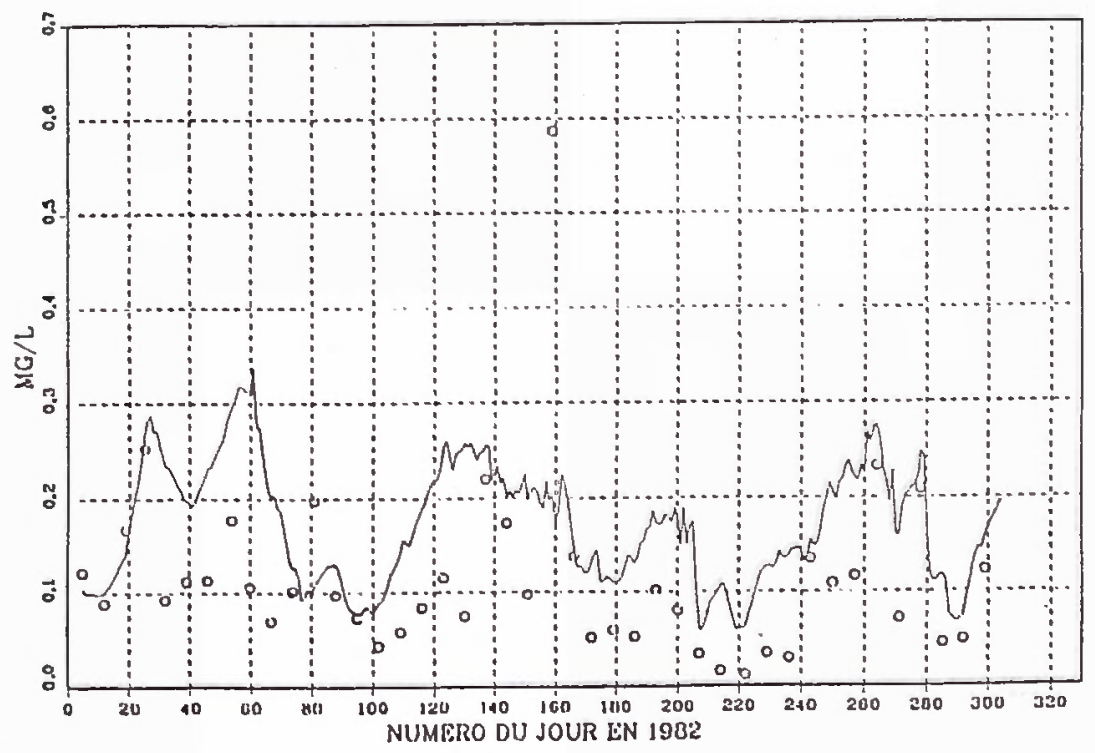

$\mathrm{PO} 4$

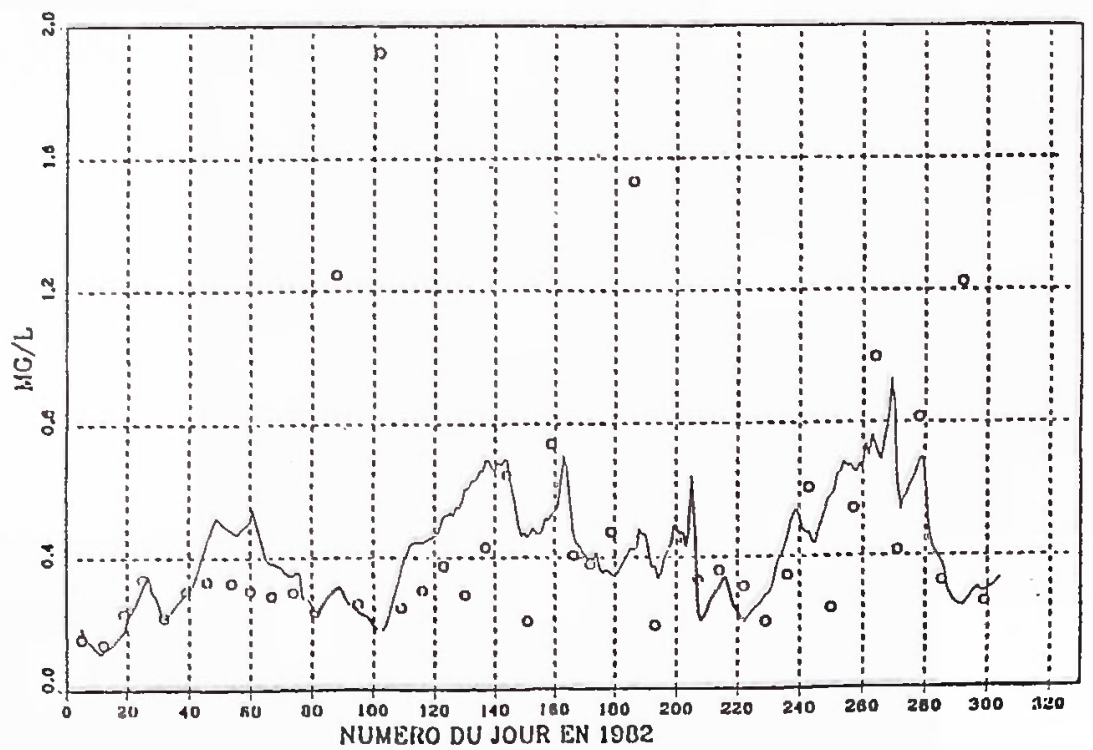

Fig. 9c. - Veritication phase of the model in 1982. Comparison of calculations-measurements results at Avanne for ammonium (mg $\mathrm{N} /$ ) and orthophosphates (mg PO $4 /$ ). 
dering the present state of knowledge regarding the pace of the polluters'activities.

This verification phase confirms that hydraulic residence time during the summer is the main factor explaining the differences in chlorophyll a concentrations observed in space and over time. In addition, as one progressively depasses summer conditions the length of exposure to the sun and the water temperature become more decisive, progressively thwarting the possibility of substantial phytoplanktonic growth.

The calculation of dissolved oxygen content effectively shows that as in 1981, concentrations are generally the highest upstream (Lougres, Baume) and the lowest downstream (Avanne, Orchamps). It can also be observed that the model accurately determines the less oxygenated periods $\left(151^{\text {st }}, 199^{\text {th }}\right.$ and $264^{\text {th }}$ days of 1982) taking place between May and October - which is quite rightly considered as potentially the most critical period of the year - although the oxygenation levels obtained may differ by up to $1 \mathrm{mg} / \mathrm{l}$ from the measurements.

\section{POSSIBLE IMPACT OF THE CONSTRUCTION OF THE HIGHER-CAPACITY NAVIGATIONAL CANAL}

The new hydraulic characteristics of the river after the construction of the larger canal determined from the profiles provided by the Compagnie Nationale du Rhône (CNR), are then incorporated into the model. The ma- jor discontinuities introduced by the twelve large dams projected make it necessary 1) to define a finer distribution of the calculation zone to secure sections that are more homogenous in terms of depth and velocity (three sections are thus distinguished between two large dams and the calculation time step is one hour) and 2) to employ an appropriate formula to model oxygen exchanges in the waterfalls.

No change is made to the numerical values of the other parameters of the model, apart from benthic demand at $20^{\circ} \mathrm{C}$ which is assumed to increase by reason of the general decreasing of velocities and taken everywhere to be $3 \mathrm{~g} \cdot \mathrm{m}^{-2} \cdot \mathrm{day}^{-1}$, and the speed of sedimentation (SED3) of the BOD which is taken equal to 0.35 m.day ${ }^{-1}$ (which does not greatly alter the results of the model relating to dissolved oxygen). This last value is the average value of distribution over space adopted in the model of the Doubs as corresponding to present conditions.

The assumption of vertical homogeneity was retained; however further investigation is warrented in the near upstream section of the large dams under projection.

The trends observed in the summer are as follows : taking daily average temperature, the difference between conditions of the rivers now and after construction of the canal generally remains in the range $\pm 3^{\circ} \mathrm{C}$. The increased depth which causes greater thermal inertia of the water columns is the main factor explaining the change in thermal flow of the river 
downstream from Baume, whereas between Lougres and Baume the lengthening of hydraulic residence times and the increase in depth both play a role in the temperature change.

Phytoplanktonic biomass concentrations generally decline in summer due to the increase of water depth : under these conditions, less light penetrates the average water column, so that the algal growth rate diminishes and potential phytoplankton " concentrations decrease.

Most of the time in summer, the lengthening of residence time, whose own effects is to allow phytoplankton to faster reach its equilibrium concentration with the local conditions of the medium (Gosse and al., 1984), does not generate higher phytoplankton concentrations downstream from Baume-les-Dames for the main reason that in present conditions, phytoplankton concentration are often close to or greater than the future potential concentrations (figure 10).

Since in the present state phytoplankton plays a major role in the dissolved oxygen and nutrient balances in the summer, all these variables are quite strongly influenced by the overall decline in phytoplanktonic concentration (figure 11) which masks the effect of the lengthening of residence time favouring a local mineralisation.

\footnotetext{
The potential phytoplankton concentration of a river section is defined as the maximal theoretical concentration of phytoplankton biomass which could be obtained, without time limit, in a stretch of water isolated from the river but under the same hydraulic (depth), meteorological (temperature, daily sunlight), and physico-chemical (turbidity, nutrients) conditions than the river section under consideration.
}

The dissolved oxygen content tends to drop (lesser photosynthesis) and nutrient concentrations increase (lesser uptake by algae). The $\mathrm{BOD}_{5}$ tends to decrease (lesser endogeneous respiration and a smaller volume of dead algal substances) as well as organic nitrogen and phosphorus (small addition of dead phytoplankton).

The dissolved oxygen balance is also greatly influenced by proximity to large dams : upstream gaseous exchanges between air and water are reduced (low flow velocity, greater depth), and dissolved oxygen concentrations can thus be quite low if a substantial volume of oxidizable polluting substances are conveyed by the river. The downstream waterfall increases the dissolved oxygen content markedly if the concentration upstream is substantially below the saturation value. Figure 12 illustrates the longitudinal dissolved oxygen profile of the developed Doubs during two summer months (July and August 1982).

The assumption was made here that the decline in flow velocities after the development of the river does not change the level of non algal turbidity, on the principle that increased navigation on the river will tend to offset the effect of changes in flow characteristics. Since the phytoplankton variable is extremely sensitive to turbidity, and plays a dominant summer role in the system modelled, it is of interest to illustrate the effect of a $30 \%$ reduction of the non algal turbidity. As regards the simulated variables, it appears that the differences between present and post-develop- 

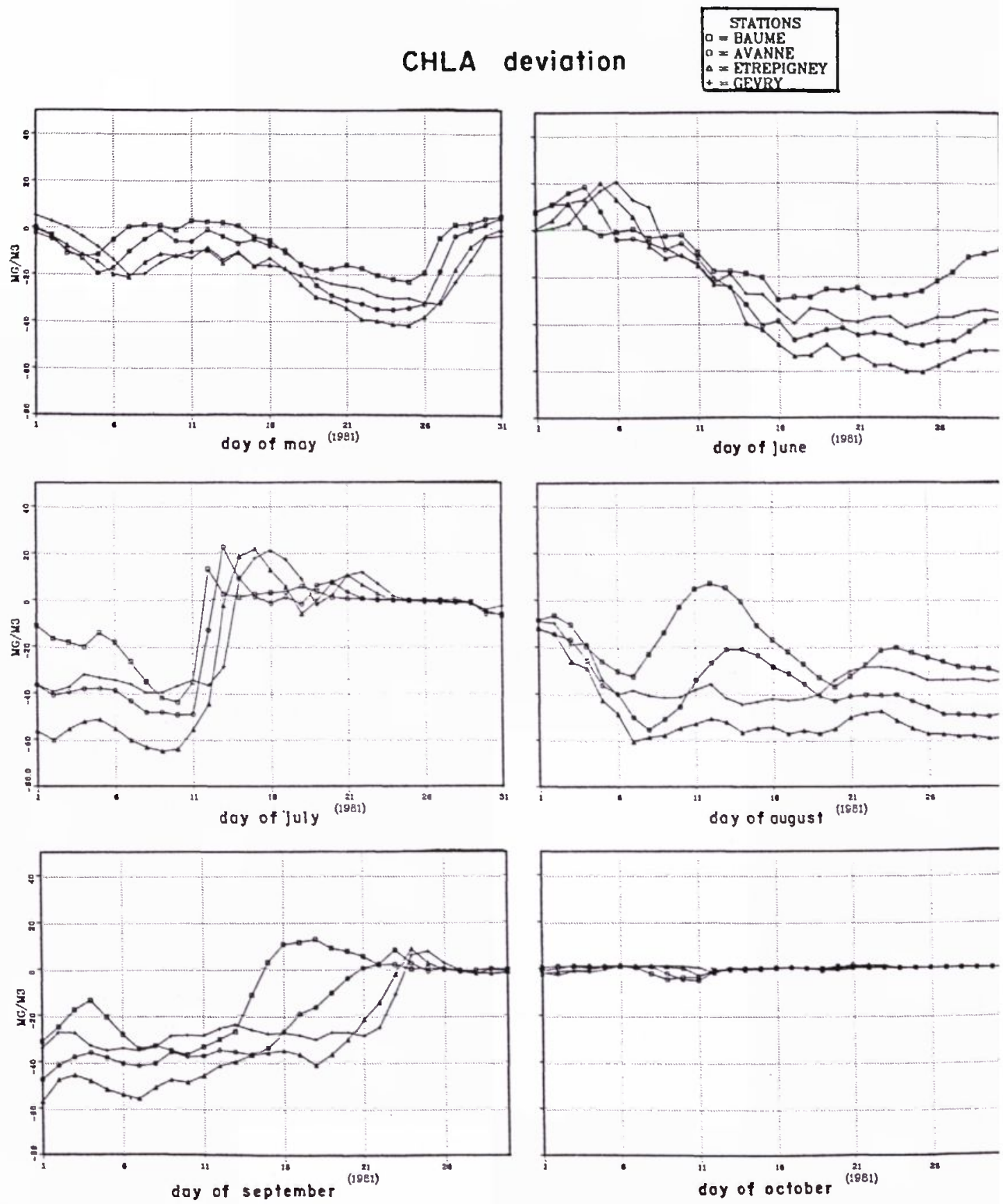

Fig. 10. - Predictive phase of the model : differences in chlorophyll a in the Doubs river between the planned (large canal construction) and the present situation (1981 reference). 


\section{dissolved oxygen deviation}
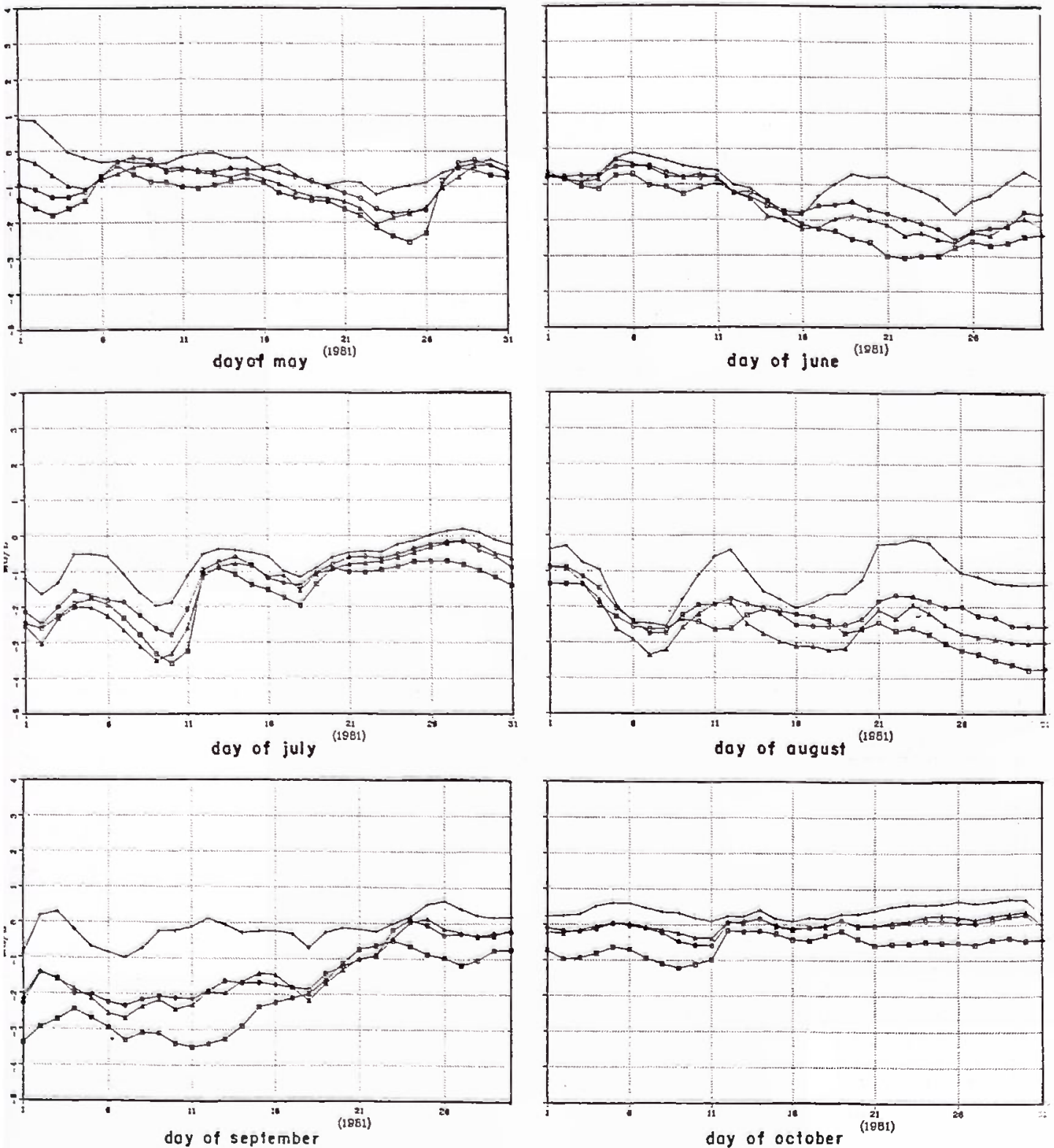

Fig. 11. - Predictive phase of the model : difference in dissolved oxygen in the Doubs river between the planned (large canal construction) and present situation (1981 reference). 
dissolved oxygen

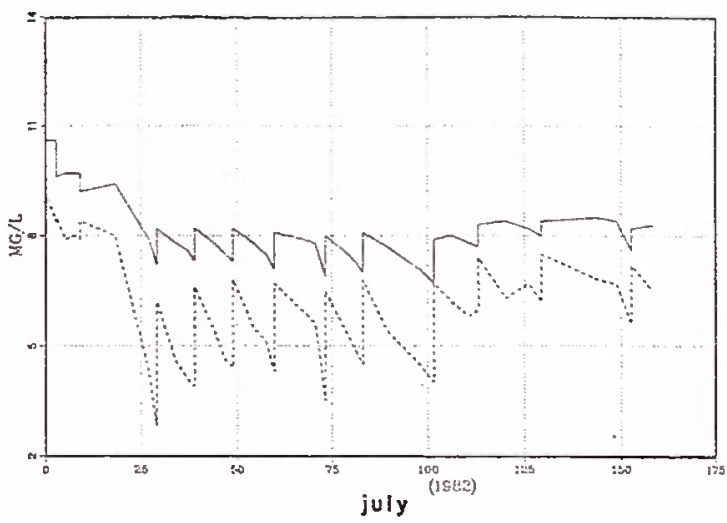

PHYTOPLANKTON

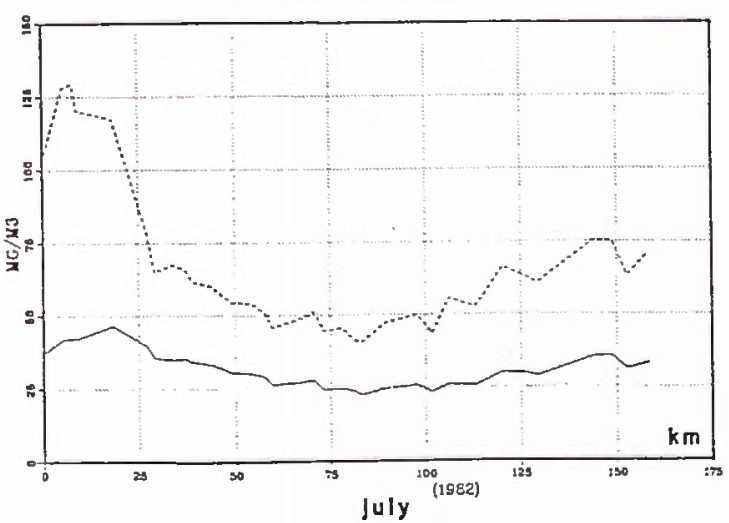

dissolved oxygen

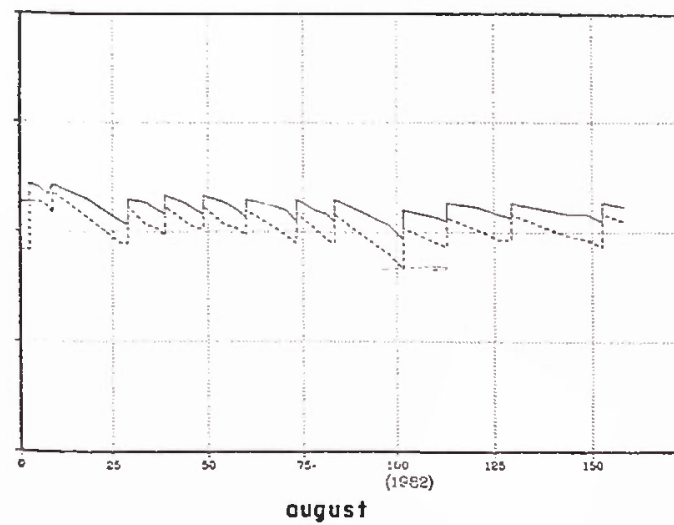

PHYTOPLANKTON

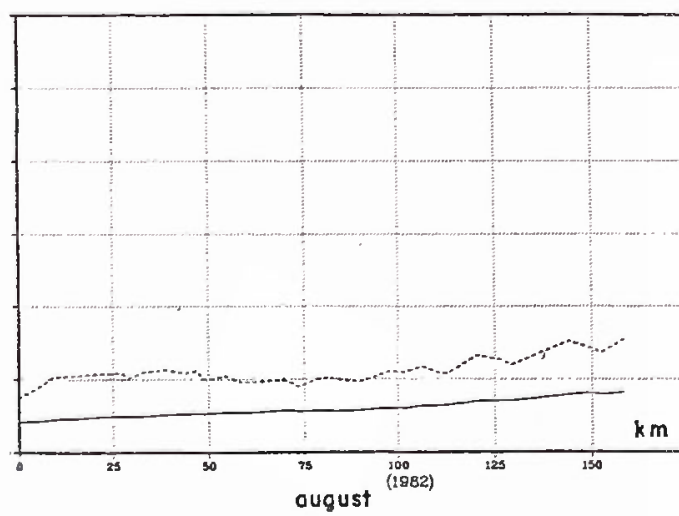

Fig. 12. - Predictive phase of the model : calculated longitudinal profiles of dissolved oxygen and phytoplankion in the Doubs river in the planned situation with large tonnage navigation (dry july and wet august 1982). The dotted profiles are the minimum values of the month, the continuous profiles are the mean values of the month. 
ment conditions are less marked (figure 13).

\section{CONCLUSION}

Insight into the water quality of the lower Doubs is given by the measurements analysis and the model developed which simulates the evolution of nine water quality variables in 1981 and 1982 : the phosphorus and nitrogen discharges emanating from the catchment basin, substances which are not yet eliminated by specific treatment, lead to high nitrogen and phosphorus concentrations in the lower Doubs. In the summer, this promotes substantial growth of phytoplankton Montbéliard downstream from Montméliard when the hydraulic residence time of the water is sufficiently long i.e., when the rate of flow is below $70 \mathrm{~m}^{3} / \mathrm{s}$ over at least one week. This biomass plays a major role in the oxygen balance and on the nitrogen cycle. In addition, it is responsible for the high $\mathrm{BOD}_{5}$ values which distort the image of the major purification projects undertaken over the last few years. However, dissolved oxygen concentrations which are greater than $5 \mathrm{mg} / \mathrm{l}$ in 1981 and 1982 , are quite satisfactory. The main factors governing dissolved oxygen balance have been assessed by the model (table 2).

This global modelling approach of the river provides a good starting point for initiating studies on a finer spatial scale (especially concerning river banks ecosystems) which would complement it, with room for improvement concerning several points (in particular with regard to the variation over time of pollution discharges and the variation over space of the kinetics of BOD decay).

The model can be used to discuss the possible effect on the simulated variables of water treatment operations or modifications in the industrial activity. Such a predictive application is given, providing and estimate of the possible changes in water quality stemming from the altered hydraulic characteristics that would be obtained after the construction of the large Rhine-Rhone canal under projection, with the continued assumption of a vertical homogeneity of the water column. It has been shown on that occasion how a moderate variation in non algal turbidity could change the model results noticeably.

\section{Acknowledgments}

Undertaken at the request of the Regional Equipment Department of Franche-Comté (French ministry of transports), this study was financed by the Franche-Comté region, the Ministry of Transport, the Ministry of the Environment and Electricité de France. The SRAE Franche-Comté and the CEMAGREF collected the data on the quality of water. Without the contributions made in the course of regular meetings of representatives of the Equipment Department (MM. MONNIOT, BOSTVIRONNOIS and FOLTETE), the SRAE Franche-Comté (MM. MASSON, ROUAULT, VIDONNE), the CEMAGREF (MM. BALLAND, BARBE and VERREL), the 

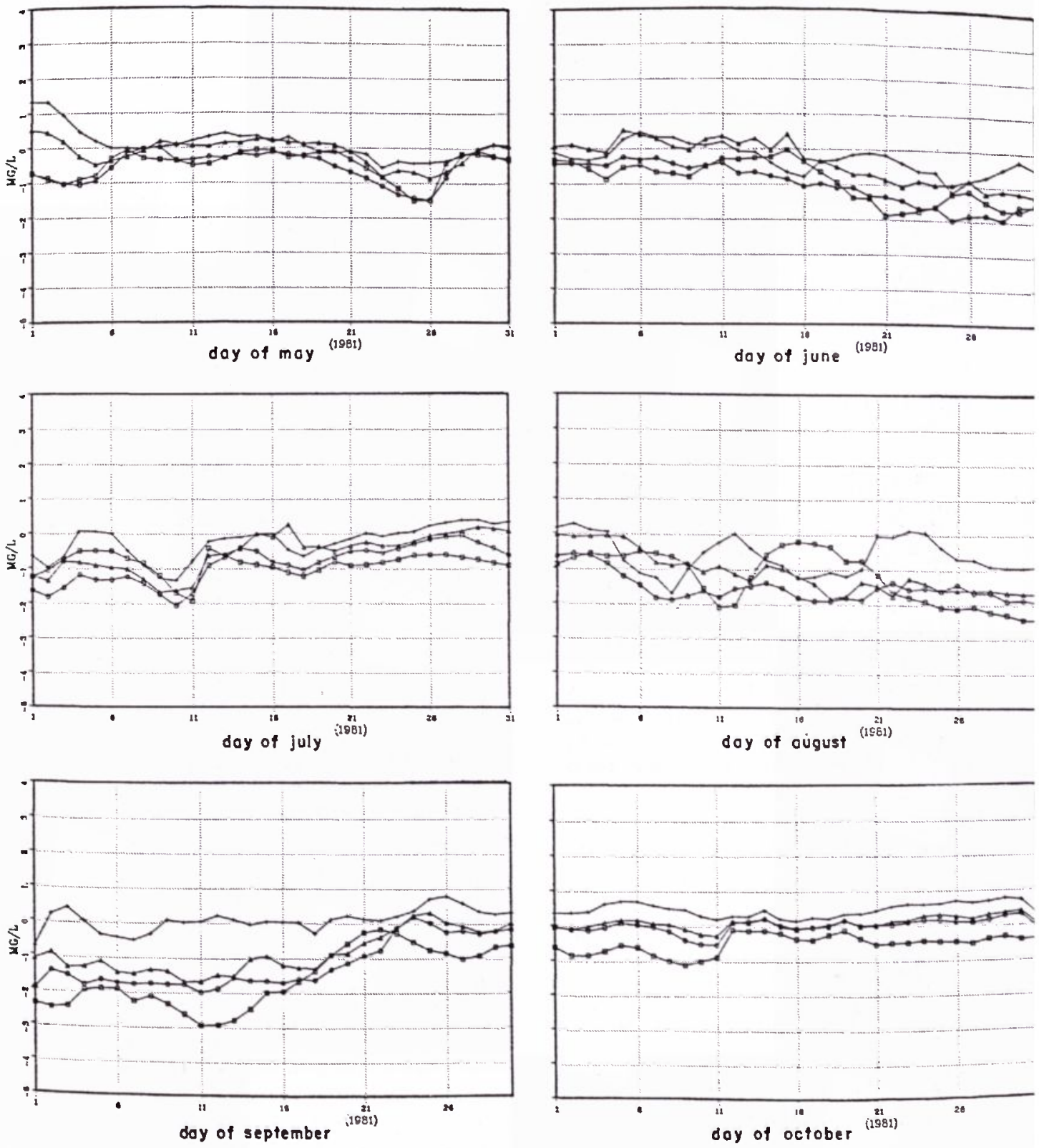

Fig. 13. - Predictive phase of the model : difference in dissolved oxygen between the planned (large canal construction) and the present situation. With the hypothesis of a $30 \%$ reduction of non algal turbidity in the planned situation (1981 reference). 
Compagnie Nationale du Rhône (MM. DUBOIS and THOMAS), Besançon university (Prof. VERNEAUX) and the Navigation Department of the Doubs, the study could not have been completed.

More details concerning this study can be found in six Electricité de France reports which may be requested by contacting Direction Régionale de l'Equipement, Région FrancheComté, 48, Avenue Georges Clémenceau - F-25000 BESANÇON.

\section{REFERENCES}

Bordet, F., 1980 : Influence de l'échauffement de l'eau sur la photosynthèse dans un milieu pollué: La Seine à Porcheville. Cahiers du Laboratoire de Montereau $n^{\circ} 10 /$ September 1980, $p$. 33-48.

Chalon, E., Momal, D. and Sabaton, C., 1978 : Effets de la canalisation à grand gabarit sur la qualité des eaux du Doubs. In Modelling the water quality of the hydrological cycle. Proceedings of the Baden Symposium. IAHS publication $n^{\circ} 125$, pp. 59-67.

Chen, C.W., Smith, D.J., Lee, S., 1976 : Documentation of water quality models for the Helms Pumped Storage Project. Tetra Tech, Incorporated.

Di Toro, D.H., O'Connor, D., Thomann, R., 1971 : A dynamic model of phytoplankton population in the Sacramento-San Joaquin Delta. In Advances in Chemistry series 106. 28 R. Gould. Ed.

Golterman, H.L., 1975 : Development in Water Science. Physiological limnology. Elsevier, Amsterdam.

Gosse, Ph., 1981a : La mesure de $\mathrm{DBO}_{5}$ et modélisation du bilan d'oxygène dissous d'un cours d'eau eutrophe aérobie. Electricité de France, EDF/DER/HE31/81 $n^{\circ} 40$ report.

Gosse, Ph., 1981b : Water quality modelling in the Loire river. In Energy and Ecological Modelling. Developments in Environmental Modelling. Mitsch, Bosserman, Klopatek Eds. Elsevier. Amsterdam.

Gosse, Ph., Albignat, J.P., Coantic, M., 1983: Aeration mechanisms in the dissolved oxygen balance of a harnessed stream. In Proceedings, 20th IAHR Congress. Moscow 1983. Vol. 3, pp. 156-169.

Gosse, Ph., Gras, R., Khalanski, M., 1984: Trophic state of an ecosystem: a simplified model to disclose the main factors controlling phytoplankton dynamics, Electricité de France, EDF/DER/HE31/84 $n^{\circ} 7$ report.

Gras, R., 1969 : Simulation du comportement thermique d'une rivière à partir des données fournies par un réseau classique d'observations météorologiques. In Proceedings IAHR Congress, Kyoto 1969. Paper A53 Vol. 1pp. 491502.

Jacquet, J., 1983 : Simulation of thermal regimes of rivers. In Mathematical modeling of water quality. G.T. Orlob Ed. International Series on applied systems analysis. Vol. 12. pp. 150-175, J. Wiley and sons, Chichester.

O'Connor, D., Dobbins, 1956 : The mechanism of reaeration in natural streams "Transactions, ASCE Vol. 123.

Poulin, M., 1980 : Modélisation du comportement thermique des cours d'eau. Application au Rhin. Thesis. Université Pierre et Marie Curie. Paris 6.

Steele, J.H., 1962 : Environmental control of photosynthesis in the sea. Limnology and Oceanography, 7.

Verneaux, J., 1973 : Cours d'eau de Franche-Comté (massif du Jura). Recherches écologiques sur le réseau hydrographique du Doubs - essai de 
biotypologie. Thesis. Faculté des Sciences et Techniques de l'Université de Besançon.

\section{Nomenclature}

$B E N_{20}$ benthic demand at $20^{\circ} \mathrm{C}$

$\mathrm{C}_{\max }$ maximum growth rate for phytoplankton

CP growth rate for phytoplankton

DP loss rate for phytoplankton

$f$ produced oxygen to produced biomass ratio

$f_{n}$ intracellular nitrogen to biomass ratio

$f_{p}$ intracellular phosphorus to biomass ratio

g1, g2, g3 temperature functions acting on kinetics

$H$ mean water depth $(m)$

Io solar irradiation of the water surface

Is saturation irradiation

$k_{e}$ solar extinction coefficient in the water $k^{\prime}$ e extinction coefficient without live algae

$\mathrm{K}_{1,20} \mathrm{BOD}$ decay at $20^{\circ} \mathrm{C}$

$\mathrm{K}_{2,20}$ aeration coefficient at $20{ }^{\circ} \mathrm{C}$

$\mathrm{K}_{3,20}$ POR decay at $20^{\circ} \mathrm{C}$

$\mathrm{K}_{4,20}$ endogeneous respiration at $20^{\circ} \mathrm{C}$

$\mathrm{K}_{5,20}$ NOR decay at $20^{\circ} \mathrm{C}$

$\mathrm{K}_{6,20}$ nitrification rate at $20^{\circ} \mathrm{C}$

$K_{n}$ half-saturation constant for nitrogen

$K_{p}$ half-saturation constant for phosphorus

$L$ first stage BOD (biochemical oxygen demand)

LIMNUT growth limitation due to nutrients depletion
MP death rate for phytoplankton

$\mathrm{m}_{1}$ mortality coefficient at $20^{\circ} \mathrm{C}$

$\mathrm{m}_{2}$ mortality coefficient at $20^{\circ} \mathrm{C}$

$\mathrm{n}$ oxygen to nitrogen ratio

$\mathrm{NH} 4$ ammonium

NO3 nitrate

NOR nitrogen non avalaible for growth

OD dissolved oxygen

OS saturation value of dissolved oxygen

PHY phytoplankton biomass

PO4 avalaible phosphorus for growth

POR phosphorus non avalaible for growth

$Q$ rate of flow $\left(\mathrm{m}^{3} / \mathrm{s}\right)$

qi continuous discharges of pollution in a reach $\left(\mathrm{g} \cdot \mathrm{m}^{-1} \cdot \mathrm{day}^{-1}\right)$

$r$ aeration efficiency for weirs

RAY growth limitation due to inadequate solar irradiation

$R P$ respiration rate for phytoplankton

SEDt sedimentation velocity for POR

SED2 sedimentation velocity for NOR

SED3 sedimentation velocity for $L$

$t$ time (day)

$\mathrm{T}$ water temperature $\left({ }^{\circ} \mathrm{C}\right)$

$U$ stream velocity $(\mathrm{m} / \mathrm{s})$

$V$ wind speed at $2 \mathrm{~m}$ above surface $(\mathrm{m} / \mathrm{s})$

$\alpha, \alpha^{\prime}$ toxicity coefficients for algal growth in very polluted waters

B turbidity coefficient for phytoplankton

$\mathrm{p}, \mathrm{n}$ proportions of phosphorus and nitrogen in dead phytoplankton which can almost immediatly be assimilated

$\Delta \mathrm{H}$ weir heigth $(\mathrm{m})$

$\eta$ proportion of nitrogen assimilated under $\mathrm{NH} 4$ form 


\section{ERRATA}

Tome 1, volume 1/2 - 1989

Ph. Gosse - Monitoring the quality of water in the Doubs river (France)

1) Les profils de nitrate et d'ammonium sur les figures $9 b$ et $9 c$ sont exprimés en $\mathrm{mg} \mathrm{NO} / \mathrm{l}$ et $\mathrm{mg} \mathrm{NH} / \mathrm{l}$ respectivement et non en $\mathrm{mg} \mathrm{N} / \mathrm{l}$ comme indiqué.

Nitrate and ammonium profils on figures $9 b$ and $9 c$ are expressed in $\mathrm{mg} \mathrm{NO} / \mathrm{l}$ and $\mathrm{mg} \mathrm{NH} / 4$ respectively, and not in $\mathrm{mg} \mathrm{N} / \mathrm{l}$ as stated.

2) Dans la légende de la figure 12, la dernière phrase est: the dotted profiles are the minimum or maximum values of the month, the continuous profiles are the mean values of the month.

In the legend of figure 12 , the last sentence is : the dotted profiles are the minimum or maximum values of the month, the continuous profiles are the mean values of the month. 